\title{
TRILEMMAS AND TRADEOFFS: Living with Financial Globalization
}

\author{
Maurice Obstfeld \\ University of California, Berkeley
}

This paper evaluates the capacity of emerging market economies (EMEs) to moderate the domestic impact of global financial and monetary forces through their own monetary policies. I present the case that those EMEs able to exploit a flexible exchange rate are far better positioned than those that devote monetary policy to fixing the rate-a reflection of the classical monetary policy trilemma. Indeed, this ability was critically important in EMEs' widely successful response to the Global Financial Crisis (GFC) of 2007-2009.

However, exchange rate changes alone do not insulate economies from foreign financial and monetary developments. While potentially a potent source of economic benefits, financial globalization does have a downside for economic management. It worsens the tradeoffs monetary policy faces in navigating among multiple domestic objectives. This drawback of globalization raises the marginal value of additional tools of macroeconomic and financial policy.

Unfortunately, the availability of such tools is constrained by a financial policy trilemma, distinct from the monetary trilemma. The second trilemma posits the incompatibility of national responsibility for financial policy, international financial integration, and financial

An earlier and shorter version of this paper was presented at the 17th Annual Conference of the Central Bank of Chile, Santiago, Chile (November 2013). I thank Sandile Hlatshwayo for long-suffering research assistance and comments, and the Risk Research Center at UC Berkeley for financial support. Menzie Chinn, Pierre-Olivier Gourinchas, and Jay Shambaugh also provided helpful comments, as did participants in a seminar at the University of Chicago's Becker-Friedman Institute. For further helpful insights, I thank my discussants at the Inaugural Asian Monetary Policy Forum (May 2014), Claudio Borio and Jonathan Ostry, as well as my discussants at the 13th BIS Annual Conference (June 2014), Otmar Issing and Takatoshi Ito, Gong Cheng, Menzie Chinn, Michael Klein, Gian Maria Milesi-Ferretti, and Jay Shambaugh graciously provided data. All errors are mine.

Global Liquidity, Spillovers to Emerging Markets and Policy Responses, edited by Claudio Raddatz, Diego Saravia, and Jaume Ventura, Santiago, Chile. ( 2015 Central Bank of Chile. 
stability. It therefore impedes effective national prudential policies when capital markets are open to cross-border transactions. ${ }^{1}$

My argument that independent monetary policy is feasible for financially open EMEs, but limited in what it can achieve, takes a middle ground between more extreme positions in the debate about monetary independence in open economies. On one side, Woodford concludes: "I find it difficult to construct scenarios under which globalization would interfere in any substantial way with the ability of domestic monetary policy to maintain control over the dynamics of inflation." However, his pre-GFC analysis leaves aside financialmarket imperfections and views inflation targeting as the only objective of monetary control. On the other side, Rey (2013) argues that the monetary trilemma is really a dilemma, because EMEs can exercise no monetary autonomy from United States policy (or the global financial cycle) unless they impose capital controls.

The outline of this paper is as follows. First, I present an overview of the capital flow problem for EMEs. Then, I review mechanisms through which monetary policies and the financial cycle in advanced economies, especially in the U.S., are transmitted to EMEs. One potent mechanism works through interest rate linkages, but financial conditions can also migrate through other channels. Thus, there is a global financial cycle that does not coincide with global monetary-policy shifts (Borio, 2012; Bruno and Shin, 2013; Rey, 2013), and exchange-rate changes alone do not fully offset its effects. The next section sets out empirical evidence on interest rate independence in EMEs, adding to the existing literature by analyzing long-term interest rates. The results leave no doubt that countries that do not peg their exchange rates exercise considerable monetary autonomy at the short end of the term structure; but longterm interest rates are more highly correlated across countries, with little regard for the exchange-rate regime.

In the penultimate section, I describe the relationship between policy trilemmas and tradeoffs in open economies. I present my argument that the fundamental problem for open EMEs is not ineffective monetary policy, per se. The problem is a more difficult tradeoff among multiple objectives, the result of a shortage of reliable policy instruments for attaining those objectives simultaneously. ${ }^{3}$

1. See Schoenmaker (2013) for a broad survey.

2. See p.14 of Woodford (2010).

3. In a closely related spirit, Filardo, Genberg, and Hofmann (2014) propose a "three-pillar" policy strategy for emerging economies—one that navigates among price stability, financial stability, and exchange rate goals. 
A brief final section outlines future research directions and also describes how some limited initiatives in international policy cooperation might soften the harsh tradeoffs that EMEs now face.

\section{Overview}

Since the nineteenth century, emerging and frontier regions have been subject to the ebb and flow of lending from richer countries. Even in the last century, powerful lending cycles buffeted those regions in the 1920 s, the 1970 s through the early 1980 s, the early 1990 s, the mid-2000s, and after 2009.

However, with the development of emerging financial markets and the general expansion of global finance, recent decades have revealed some new patterns. First, many emerging countries, which Nurkse (1954) ruled out as portfolio investment destinations based on their colonial history, now receive such flows. Perhaps history is not always destiny after all. Second, even emerging economies with persistent current account surpluses-including several Asian economies-may experience gross capital inflow surges, the result of rich-country portfolio shifts in favor of emerging assets. Where these portfolio demands are accommodated through the home central bank's intervention, the financial inflows finance foreign reserve increases. Where the central bank instead allows currency appreciation, net private claims by foreigners still rise, albeit gradually over time, as a result of a reduced current account balance. ${ }^{4}$ China's case shows how both mechanisms can operate at once. Whether the central bank intervenes or not, domestic financial conditions are affected immediately; although, the expansionary effect is probably bigger

4. In a pair of classic contributions, Calvo, Leiderman, and Reinhart $(1993 ; 1996)$ linked net emerging market capital inflow surges to monetary ease in the advanced countries. Their theme remains highly relevant, of course, and is the central focus of this paper. For documentation on gross capital flow surges and reversals, see Cowan, De Gregorio, Micco, and Neilson (2008), Forbes and Warnock (2012), and Broner, Didier, Erce, and Schmukler (2013). On long-term cycles in capital flows, see Bacha and Díaz-Alejandro (1982), Eichengreen (1991) and Obstfeld and Taylor (2004). Of course, the pattern of net capital flows remains puzzling, as discussed by Prasad, Rajan, and Subramanian (2007) and Gourinchas and Jeanne (2013). On the importance of financing conditions as reflected in gross capital flows, see Borio and Disyatat (2011). 
when intervention occurs and causes an increase in the domestic money supply and domestic bank credit. ${ }^{5}$

Capital inflow surges can cause a range of dislocations-not the least of which is to create a range of vulnerabilities to subsequent capital-flow reversals. After the GFC, industrial countries' recoveries slowed by effects of private and public debt overhang, relying on continuing monetary stimulus in the form of ultra-low policy interest rates (sometimes coupled with forward guidance) and unconventional quantitative measures. In general, however, the EMEs-at least those that avoided big debt run-ups $-{ }^{6}$ had suffered less in the crisis. With economies growing more briskly than those of advanced countries, these EMEs did not require abnormally accommodative monetary policy settings. Currencies, bonds, equities, and real estate appreciated because of the resulting global portfolio shift into EME assets. Appreciation contributed to financial stability (as well as competitiveness) concerns, and countries that resisted exchange-rate change through intervention saw greater pressure on domestic asset prices, on domestic credit growth, and on general product price levels. Those pressures have now left EMEs more vulnerable to a reversal of global financial flows.

Clearly then, EMEs have an interest in tempering the effects of global portfolio shifts, especially when the sequence is capital feast followed by capital famine. How can EMEs use their macroeconomic tools to do so? Astute observers have long known that in principle monetary policy is vital, but cannot furnish the sole to respond to capital inflow surges. Shortly after the Tequila crisis of two decades ago, for example, Calvo, Leiderman and Reinhart (1996) wrote: ${ }^{7}$

The countries that have been the most successful in managing capital flows... have implemented a comprehensive policy package and not relied on a single instrument. At the outset of the surge in inflows, these countries reacted by treating inflows as temporary and resisted a nominal exchange rate appreciation; the foreign exchange intervention was mostly sterilized. As the inflows

5. For some suggestive evidence that this is the case, and that net private capital inflows are likely to create more financial fragility in economies with less flexible exchange-rate regimes, see Magud, Reinhart, and Vesperoni (2014). The theoretical perspective I sketch later in this paper suggests, however, that a more nuanced understanding would come from studying the impacts of gross inflows, as analyzed by some of the references listed in the previous footnote.

6. See Gourinchas and Obstfeld (2012).

7. See p. 137 of Calvo, Leiderman and Reinhart (1996). 


\begin{abstract}
persisted, sterilization efforts were scaled back and the domestic currency was allowed to appreciate. To moderate the extent of the real appreciation and prevent the economy from overheating, fiscal policy was tightened. To moderate the volume of the inflows and lengthen their maturities, exchange rate flexibility was increased and measures to curb inflows were implemented.

A less productive policy mix has consisted of persistent sterilization (which keeps short-term interest rates comparatively high), heavy intervention in the foreign exchange market (which results in little short-run exchange rate uncertainty) and no controls on short-term capital movements. All of these policies have tended to provide especially strong incentives for short-term capital inflows.
\end{abstract}

Subsequent research and experience suggested, however, that for some countries, the preceding approach was difficult to implement in practice during the 1990s. Perhaps most importantly, currency mismatch and the need for an easily verifiable nominal anchor sometimes imparted a strong policy bias toward exchange-rate stability in EMEs, thereby constraining monetary policy (Hausmann, Panizza, and Stein, 2001; Calvo and Reinhart, 2002). In the presence of fixed or highly managed exchange rates, a number of policy failures set the stage for the EME crises of the late 1990s.

More recently, the position of EMEs has evolved considerably. As noted above, international financial flows have increased in scale, particularly in gross terms, driven in significant part by international banking flows. At the same time, domestic financial systems have expanded and deepened. While, for EMEs, these changes are not as extreme as for the advanced countries, they are still highly significant and leave EMEs more exposed to shifts in global financial-market sentiment. For example, a big sell-off of domestic assets by foreign investors is likely to induce a significant exchange rate change before enough buyers come forward to restore market equilibrium. EME corporates and banks increasingly issue bonds offshore, and these foreign-currency liabilities-not captured in standard, residencebased net international investment position data-are a potential source of currency mismatch, as well as direct exposure to foreign financing conditions (Turner, 2014; Shin, 2013).

One manifestation of global financial linkages is the importance of cross-border credit, both in local and foreign currency (see Borio, McCauley and McGuire, 2011). Figure 1 shows the ratio of crossborder to domestic bank credit for five regions as measured in the BIS Global Liquidity Indicators. Three regularities stand out. First, 
apart from the Asia-Pacific grouping (which mixes advanced and emerging economies), cross-border credit is very significant compared to domestic bank credit-currently in the 10 to 20 percent range for the other four regions. Second, in all regions, the ratio of crossborder to domestic credit positively covaries with the global credit boom of the mid-2000s and the subsequent collapse-a reflection of the gross financial flows that helped fuel the GFC. Finally, the cross-border bank credit ratio falls secularly in Latin America and emerging Europe, from a very high level at the start of the millennium to a level roughly on the same order as the U.S. and the eurozone. In part, declining reliance on cross-border bank lending reflects domestic financial deepening; in part, it reflects retrenchment in banks' global activities and growth in bond finance after the GFC. While perhaps reduced compared to its level in 2000, considerable exposure to global banking fluctuations remains for many EMEs, and evidence indicates that net cross-border debt flows fuel domestic credit growth. ${ }^{8}$ Moreover, increasing EME recourse to non-bank funding sources has created new exposures, some not even visible in residence-based data on gross external liabilities, such as the Lane and Milesi-Ferretti (2007) data for selected countries shown in figure $2 .^{9}$

8. Locational banking data such as these (based on the residence principle) may well understate banking exposure, as the head offices of domestic affiliates are likely to divert funding in a crisis. See Cetorelli and Goldberg (2011). Lane and McQuade (2014) document a link between net cross-border debt flows and domestic credit growth.

9. For this figure, I exclude tax havens as well as all countries with GDP below $\$ 2$ billion in 2012 . 
Figure 1. Cross-Border Credit as a Fraction of Domestic Credit, by Region

Cross-border/domestic credit ratio (percent)

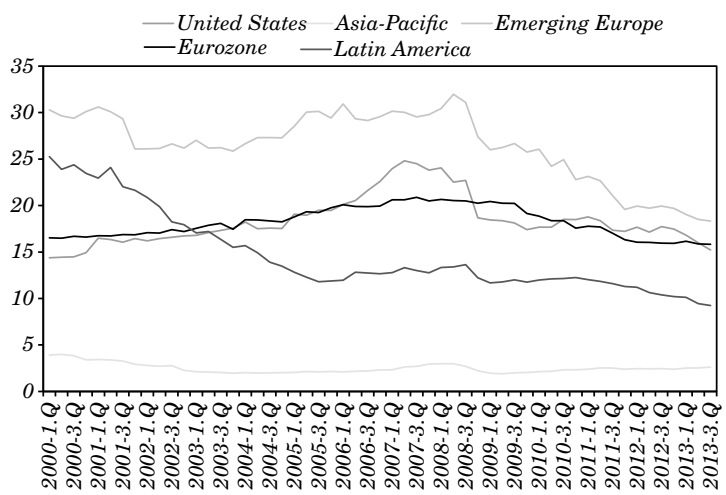

Source: BIS, Global Liquidity Indicators.

Figure 2. Gross External Liabilities Relative to GDP, by Region

Gross foreign liabilities/GDP, GDP weighted averages

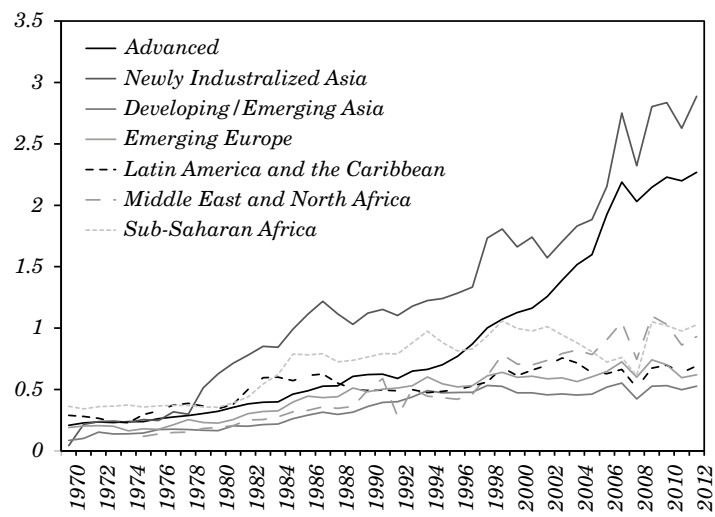

Source: Updated data from Lane and Milesi-Ferretti (2007), courtesy Gian Maria Milesi-Ferretti. 
Counteracting the increased vulnerabilities are some policy and institutional enhancements. ${ }^{10}$ Over time, EMEs have shifted their gross liability positions away from debt in the direction of equity instruments (portfolio equity and FDI). In this respect, international financial integration promotes international risk sharing and can therefore be a stabilizing factor. Figures 3 and 4 illustrate the recent dramatic shift of external liabilities toward equity (see also Lane and Shambaugh, 2010 and Prasad, 2011). ${ }^{11}$ Currency depreciation automatically devalues this portion of external liabilities, but even the remaining external and domestic debt is increasingly denominated in domestic currency (Lane and Shambaugh, 2010; Miyajima, Mohanty and Chan, 2012; Turner, 2012). The growth of domestic bond markets-most advanced among the EMEs in Asia, where corporates are significant players alongside governmentshas been an important supporting factor. Moving from a nominal exchange rate anchor to some alternative (often a managed float within the context of an inflation target) has paid dividends for many EMEs, both in providing generally moderate inflation and in relieving the government of the need to defend a definite line in the sand with monetary policy or reserves. The second dividend has generally reduced the incidence of foreign exchange crises, in part, by freeing foreign exchange reserves for purposes other than defense of an exchange rate target..$^{12}$ Of course, more reliably moderate inflation itself has helped to promote domestic-currency denomination of domestic and foreign liabilities.

10. See Obstfeld (2014) for a more detailed survey and discussion.

11. In general, the picture in emerging Europe (where some countries are in the eurozone) is more mixed and not as favorable to foreign equity finance. The data in the figures of course reflect stock market price fluctuations, but the trends are still clear. Broadly speaking, if one starts in 1970 , the data describe a J shape. Prior to gaining access to private lending markets in the 1970 s, developing countries relied primarily on FDI for private foreign financing. Access to debt finance allowed a fall in the FDI share. Only much later did portfolio equity inflows become important. The United States is shown in figure 3 for the purpose of comparison. A caveat to figures 3 and 4 is that the Lane and Milesi-Ferretti data, which are residence-based, do not capture offshore bond issuance by domestic nationals.

12. Ghosh, Ostry, and Qureshi (2015) discuss evidence on the susceptibility of hard and adjustable pegs to crisis. If foreign exchange reserves are not dedicated to defense of the exchange rate, more of them can be used in lender-of-last resort operations in support of domestic entities with short-term foreign-currency liabilities. On the relation between reserve use during the GFC and economic performance, see Dominguez, Hashimoto, and Ito (2012). 
Figure 3. External Equity Liabilities Relative to Total External Liabilities, by Country: Western Hemisphere Fraction

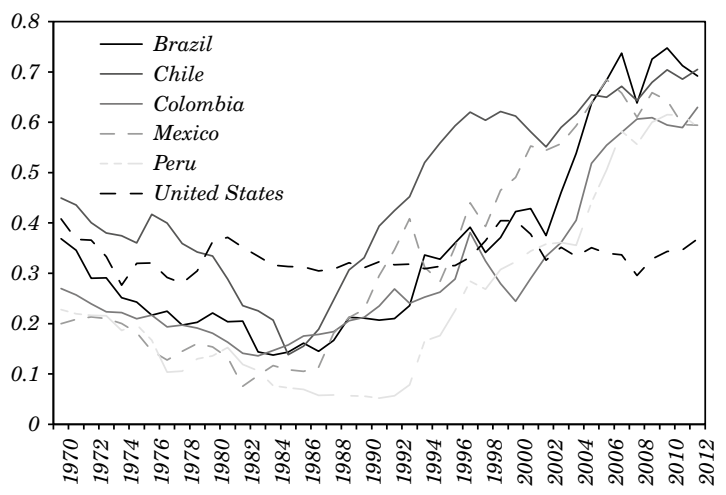

Source: Updated data from Lane and Milesi-Ferretti (2007).

Figure 4. External Equity Liabilities Relative to Total External Liabilities, by Country: Asia

Gross foreign liabilities/GDP, GDP weighted averages

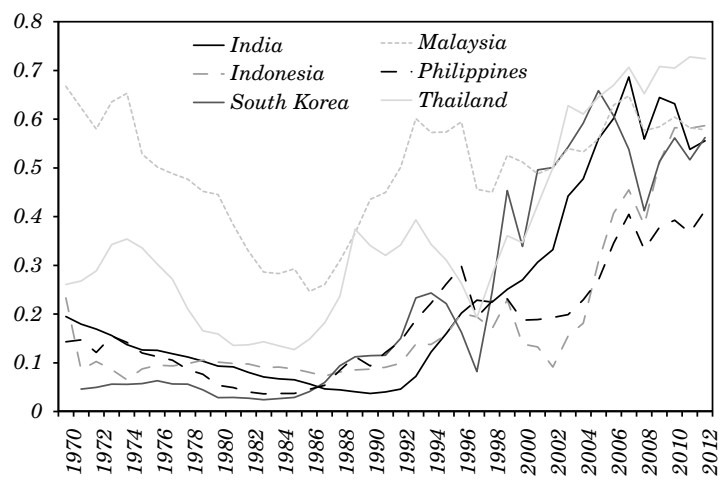

Source: Updated data from Lane and Milesi-Ferretti (2007). 
A more effective approach to financial oversight, typically including a macro-prudential component, has supplemented these macroeconomic regime changes. Many EMEs, especially in Asia, have accumulated large stocks of foreign exchange reserves that allow the domestic monetary authority to play a lender-of-last-resort role for financial institutions with short-term foreign-currency liabilities. Market perceptions that authorities are able and willing to play that role, as many did quite effectively during the GFC, are a stabilizing factor for capital flows. Moreover, large precautionary reserve holdings are complemented by a higher level of capitalaccount restrictions than in advanced economies; Bussière et al. (2014) present evidence on the stabilizing effects of reserve stocks and the use of capital-account measures. Figure 5, which is borrowed from their paper, shows that while advanced and advancing countries alike have liberalized cross-border financial flows over the past three decades, the developing/emerging group has, on average, liberalized less and accumulated more international reserves in the process. ${ }^{13}$

To what degree have the preceding structural changes insulated EMEs from monetary shifts and financial cycles in advanced countries? Both during the accommodative phase of advancedcountry monetary policies following the GFC and, more lately, as markets have come to anticipate the tapering of accommodation in the United States, EMEs showed their habitual reluctance to let exchange rates bear the full adjustment burden. Indeed, some of the very structural changes cited as enhancements for EME stability could have downsides. Domestic bond markets, if dominated by foreign asset managers and lacking big domestic players such as pension funds and insurance companies, could be quite volatile, with long-term bond returns tightly linked to those in advanced-country markets (Shin, 2013) ${ }^{14}$ Moreover, if foreign holders of EME-currency bonds hedge the currency risk with counterparts in the issuing country, this potentially creates a currency mismatch: the domestic counterparts have incurred a foreign-currency liability which (leaving aside the associated forward claim to a domestic-currency payment from the bond holders) is equivalent to foreign-currency bond issuance (He and McCauley, 2013).

To diagnose and assess the threat from ongoing potential

13. Figure 5 uses the Chinn and Ito (2006) measure of capital-account openness.

14. Highly diversified fund managers might have little incentive to focus on particular countries' economic fundamentals, as argued by Calvo and Mendoza (2000). 
Figure 5. Financial Openness and International Reserves of Advanced and Developing/Emerging Countries

By year

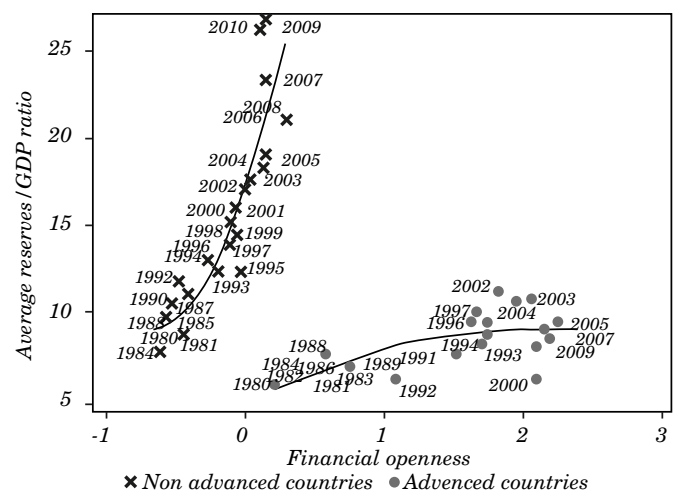

Source: Bussière et al. (2014), courtesy Menzie Chinn, based on the updated Chinn-Ito (2006) index.

vulnerabilities, it is important to carefully consider the transmission mechanisms between advanced and EME financial markets, and whether there are effective tools that EMEs can use to cope with financial shocks from abroad.

\section{Transmission Mechanisms}

In the early 1970 s, inflation surged worldwide. One obvious mechanism driving synchronized global inflation was the system of fixed exchange rates central to the Bretton Woods system, under which all countries pegged to the U.S. dollar (thereby surrendering monetary autonomy) while the U.S. retained monetary discretion (thereby dominating global monetary conditions). Both relatively loose monetary policy in the U.S., together with a huge speculative portfolio shift away from the dollar in anticipation of its debasement, led to big increases in foreign exchange reserves and money supplies outside of the United States.

A major motivation for the subsequent move to generally floating exchange rates (at least among industrial economies) was, therefore, to regain control over domestic inflation. Yet, industrialcountry inflation rates did not diverge. They rose in concert in the 
1970s, continuing even after the abandonment of fixed exchange rates, and largely fell starting in the following decade. Ciccarelli and Mojon (2010) document a powerful common component in 22 OECD countries' inflation rates over the 1960-2008 period. EME inflation rates remained higher in some countries throughout the 1980s, notably in Latin America, but those rates also converged downward starting in the 1990s. While trend inflation rates still differ across countries, the cross-country range of variation has become relatively small. The proposition that countries can control their inflation rates over the long term is widely accepted, and observed inflation convergence is regarded as a country-specific or currency union-specific phenomenon reflecting synchronized improvements in economic literacy and economic governance. ${ }^{15}$

The degree of national control over short- to medium-term macro developments (including but not restricted to price-level dynamics) is more controversial. When countries' financial markets are linked, even imperfectly, macroeconomic models incorporating realistic good- or asset-market frictions imply that policy and other shocks will be transmitted to trading partners, possibly causing unwanted spillovers even when currency exchange rates float freely. Two related questions have been especially prominent in recent debate about the scope for independent and effective monetary policy by EMEs. First, can EMEs offset shifts in advanced-country monetary policies-most importantly U.S. monetary policy-through their own monetary instruments? Second, in the face of a global financial cycle that is in principle distinct from monetary policy cycles-but which also causes portfolio shifts with respect to EME assets-what scope do EMEs have for an effective policy response? Some recent analysis has been pessimistic. Perhaps most provocatively, Rey (2013) argues that EMEs have essentially no room for monetary policy that diverges from U.S. conditions: the monetary trilemma is really a dilemma, with independent monetary policy possible if and only if capital markets

15. McKinnon (1982) hypothesized that even with floating exchange rates, a high degree of substitutability among the major industrial-country currencies made national inflation depend on world money-supply growth. If this view were right, even long-term inflation would be out of the hands of any single central bank. There is little theoretical or empirical support for McKinnon's "global monetarist" hypothesis, although some recent authors have used global monetary aggregates as proxy variables for global liquidity conditions. An example of the empirical critiques is Wallace (1984). 
are segmented from the outside world. On this view, global rather than national liquidity is central. ${ }^{16}$

To assess such arguments, it is useful to review some main mechanisms of transmission of foreign monetary and financial shocks to EME financial markets. ${ }^{17}$

\subsection{Direct Interest Rate Linkages}

Perhaps most fundamental in a world of integrated financial markets are direct interest rate linkages between countries, which reflect forces of cross-border arbitrage on rates of return. Conventional monetary policy manipulates a short interest rate directly but has effects at all maturities, and these effects induce portfolio shifts into foreign assets. In turn, those portfolio shifts generally affect exchange rates, asset prices, capital accounts, and macroeconomic policies abroad.

If an emerging country fixes its exchange rate against the currency of a central country (for example, the United States), then it has no choice but to match the latter's choice of policy interest rate. Moreover, provided the exchange rate peg is credibly permanent, riskfree nominal interest rates at all maturities must match those of the U.S. Thus, U.S. monetary policy is passively imported, in accordance with the monetary trilemma.

More generally, exchange-rate flexibility of various types and degrees will alter the international transmission of interest rates. If $e$ is the domestic price of the U.S. dollar, $i$ the short-term policy rate of interest, and $\rho$ a foreign-currency risk premium, then domestic and U.S. short rates will be linked by an interest-parity relationship of the form:

$i_{t}=i_{t}^{U S}+E_{t} e_{t+1}-e_{t}+\rho_{t}$

Above, the risk premium $\rho$ might reflect the covariance between the depreciation rate of domestic currency and a stochastic discount factor for domestic currency payments. Now, changes in the U.S.

16. For recent assessments of the concept of global liquidity, see Borio, McCauley, and McGuire (2011), Committee on the Global Financial System (2011), Gourinchas (2012), and Landau (2014).

17. For complementary discussions see Caruana (2012), He and McCauley (2013), and McCauley, McGuire, and Sushko (2014). 
interest rate need not feed one-for-one into $i_{t}$, depending on the behavior of the exchange rate and the risk premium. For example, if the EME central bank holds its interest rate absolutely constant when the U.S. cuts its interest rate, and the risk premium does not change, then foreign currency will appreciate sharply (a fall in the price of dollars, $e_{t}$ ), overshooting its expected future value so as to maintain interest parity. The EME central bank can still set the policy interest rate it prefers, but a sharp exchange rate change may well have effects on its economy that strongly influence the monetary policy response.

A powerful inhibition to allowing full exchange rate adjustment in such circumstances is the negative effect on domestic export competitiveness. The EME central bank may intervene to dampen appreciation, thereby (typically) acquiring international reserves and allowing a jump in the net private capital inflow into its economy. In turn, an increased money supply will likely cause a rise in domestic bank lending. Sterilization of the monetary effects (if somewhat effective) could raise longer-term rates at home and (if carried out on a large enough scale) lower them in the U.S., eliciting further pressure through the capital account. The carry-trade dynamics may be reinforced by the perception that the central bank is merely slowing an inevitable appreciation of its currency. The probable effect, in this case, therefore remains transmission of U.S. monetary ease.

Since sterilized foreign exchange intervention is often limited in its effectiveness, stronger efforts to limit currency appreciation are likely to enhance the correlation between the domestic and U.S. policy interest rates. Even when there is no intervention, consequential twoway private gross capital flows could occur, such as increased U.S. bank loans to the EME country, the proceeds of which are deposited in banks abroad. This increase in cross-border credit could well have an impact on domestic financial conditions (as suggested in partialequilibrium models such as Bruno and Shin, 2013); I return to this issue below. Even a fully floating exchange rate cannot provide full insulation from the expansion of gross foreign assets and liabilities.

Further international linkages occur through the longer-term interest rates set in bond markets. These rates affect activity in key economic sectors and drive real wealth through asset-valuation effects. As in the case of short-term interest rates, direct arbitrage between national markets links long-term rates with exchange rates, but long-term rates reflect, not only short-term rates, but also expected future short rates as well as risk factors. To the extent that 
monetary policy works through its effect on longer-term interest rates, such as mortgage rates or corporate borrowing rates, stronger international linkages between long-term rates could hamper monetary autonomy, in the sense of requiring sharper changes in short-term rates (and perhaps in forward guidance on those rates) to achieve a given desired result.

To make the discussion more precise, consider the simplest twoperiod example. So an approximate term structure model would represent the domestic nominal risk-free yield $i_{t}^{(2)}$ on a two-period discount bond as depending on an average of current and future expected short rates:

$i_{t}^{(2)}=\frac{1}{2} i_{t}+\frac{1}{2} E_{t} i_{t+1}+\tau_{t}$.

Here, $\tau_{t}$ tis a term premium that might reflect the covariance between future interest rates and a stochastic discount factor for domestic currency payments, and because of the interest parity relationship, $\tau_{\mathrm{t}}$ obviously is closely related to the currency risk premium $\rho_{\mathrm{t}}$ in general equilibrium. Subtracting from this the parallel relationship for the U.S. shows that international long-term rates obey an interest parity relationship in the form:

$$
\begin{aligned}
i_{t}^{(2)}= & i_{t}^{U S(2)}+\frac{1}{2}\left(E_{t} e_{t+1}-e_{t}\right)+\frac{1}{2}\left(E_{t} e_{t+2}-E_{t} e_{t+1}\right) \\
& +\frac{1}{2} \rho_{t}+\frac{1}{2} E_{t} \rho_{t+1}+\tau_{t}-\tau_{t}^{U S} .
\end{aligned}
$$

Exchange rate variability matters for long-term risk-free interest rate correlations across countries as well as for short, but to the extent that expected exchange-rate movements tend to slow or be reversed over time, long-rates could be more highly correlated than short rates-perhaps the EME central bank allows short-run movements, but its long-run inflation target is similar to that of the United States and expected real exchange rate changes are small. High international correlation among term premiums could also induce long-rate correlation across countries. For example, He and McCauley (2013) and Turner (2014) argue that U.S. quantitative easing policies that reduce term premiums spill over into a reduction of term premiums abroad. ${ }^{18}$ In this way, U.S. unconventional easing may be spread abroad.

18. Neely (2013) carries out an econometric study. 
Empirically, long-term interest rates tend to be more highly correlated across countries than short-term rates, consistent with results of the next section. Goodhart and Turner summarize a widely held view of the evidence:

Long-term interest rates are more correlated across countries than short-term rates. A central bank operating under a flexible exchange rate regime can set its policy rate independently of the Fed funds rate.

However, it has much less power over the long-term rate in its own currency because yields in all bond markets integrated into the financial system tend to rise whenever U.S. yields jump. Bond yields in countries with a weaker macroeconomic of financial fundamentals often rise even more. ${ }^{19}$

Why is this so? One reason, documented in the next section, is that there is mean reversion in short-term policy rate differentials. In addition, countries' term premiums appear to be increasingly correlated over time and closely linked to U.S. bond premiums (see, for example, Hellerstein, 2011; Dahlquist and Hasseltoft, 2012). Our understanding of these premiums in terms of reliable structural models is limited, but they are clearly related to investor risk aversion. In any case, to the extent that long-term rates are strongly subject to global forces, the power of short-term rates to steer the economy could diminish. While recent attention has focused on the effects on EME long-term rates of monetary-policy shifts in the U.S., even U.S. long-term rates appear subject to global influences, as evidenced by several empirical studies. Also related is the anecdotal evidence of the "Greenspan conundrum:" the relative constancy of long-term rates in the face of rising policy rates in the mid-2000s. ${ }^{20}$

The apparently high cross-country correlation in term premiums could reflect factors that drive global financial cycles-for example, changes in risk appetite-so I turn the discussion to the impact of international financial developments. ${ }^{21}$

19. See Charles Goodhart and Philip Turner, "Pattern of Policy Tightening is Different This Time," Financial Times, April 3, 2014, p. 20. See also Bernanke (2013) and Sheets and Sockin (2013).

20 . Another possibly relevant factor is that uncovered interest parity seems to hold more closely for long-term nominal interest rates than for short-term rates. See Chinn and Quayyum (2012).

21. Consistent with the financial-cycle view is the evidence of Gonzáles-Rozada and Levy Yeyati (2008) that emerging market bond spreads (on foreign-currency debt) respond strongly to proxies for U.S. risk appetite and liquidity. 


\subsection{Transmission of the Financial Cycle}

Like monetary policy, the financial cycle has effects that are transmitted abroad. The level of interest rates certainly can play a catalytic role, among other causes. ${ }^{22}$ Changes in credit volumes, including banking flows, can have strong effects across borders. The mid-2000s saw a powerful credit cycle, originating primarily in the U.S. and Europe, but also related to the pattern of global current account imbalances. Until the cycle collapsed in September 2008, most EMEs - including those in Asia-navigated it fairly successfully, although some countries experienced problems with capital inflows and appreciation.

A first transmission channel comes from the compression of risk premiums. Consider first the case just under discussion: long-term government bonds. A general decline in risk aversion originating in the U.S. might compress term premiums both at home and abroad. But the latter can be a powerful source of policy spillovers. Looking at the preceding long-term interest parity relation, we can see that the immediate exchange rate response might have to be quite big if EME long-term rates and the long-term nominal exchange rate do not adjust. For example, a 10 basis point fall in the term premium on a U.S. two-year bond would require a 20 basis point currency appreciation. Just as small movements in exchange rates can be consistent with big discrepancies between short-term interest rates, small discrepancies between long-term rates will require substantial exchange-rate movements unless offset by risk premium changes.

Financial conditions can migrate across borders by relaxing the quantitative borrowing constraints that agents may face. A financial boom in the U.S. will spill over into increased credit supply abroad, appreciating foreign currencies and raising foreign asset values. In turn, those developments will raise collateral values in the recipient countries, with a procyclical effect on their borrowing and asset markets. A number of models suggest different mechanisms through which the process could be, to some degree, self-reinforcing. Examples include Gertler and Karadi (2011), who focus on the franchise value of intermediaries as a limit to lending, and Bruno and Shin (2013), who emphasize the role of currency appreciation in strengthening unhedged borrowers' balance sheets.

22. For some evidence on the role of interest rates on U.S. bank behavior, see Dell'Ariccia, Laeven, and Suarez (2013). 
If the current account is slow to adjust in the short-run, then a financial inflow will necessarily be matched by an equal outflow. Absent central bank intervention, a higher private inflow is matched by a higher private outflow. Partial equilibrium models of banking inflows such as Bruno and Shin (2013) do not capture this consequence. ${ }^{23}$ However, the resulting expansion of gross liabilities and assets is quite likely to worsen the balance of financial stability risks, increasing the challenge for macroprudential policy. Challenges for macroeconomic policy could also be accentuated. Goldberg (2013) presents some evidence that a substantial foreign banking presence can reduce monetary independence, as measured by interest-rate independence.

A major spillover channel for easier foreign financial conditions is the compression of corporate spreads, which occurs as domestic financial conditions also ease. Figure 6 shows the behavior of South Korean domestic corporate spreads (with the Fed's target policy rate superimposed) ${ }^{24}$ Spreads are highly variable, rising with the wave of bankruptcies following the dot-com crash, rising in the South Korean credit-card crisis, and falling sharply afterward only to spike upward with the Lehman collapse in September 2008. The relationship to U.S. monetary policy is not mechanical due to the influence of common factors. Starting in mid-2004, for example, the Fed funds rate rises and South Korean spreads decline, both in response to the ongoing global boom in credit and liquidity that ended in the GFC.

\subsection{Foreign Currency Credit}

While dollar, euro, and yen credit is extended to non-residents, the dollar is dominant, with credit transactions often between two non-U.S. residents (Borio, McCauley and McGuire, 2011). Figure 7 displays some trends. Since 2000, dollar bank credit to non-banks outside of the U.S. has risen from an amount equal to 23 percent of total U.S. domestic bank credit to about 35 percent-while U.S. domestic bank credit itself has risen to a level about equal to annual U.S. GDP.

23. The development of general-equilibrium models should therefore be a research priority.

24. Spreads are for local currency yields computed relative to a South Korean government bond of the same tenor. 
Figure 6. South Korea, Corporate Bond Spreads versus U.S. Federal Funds Target

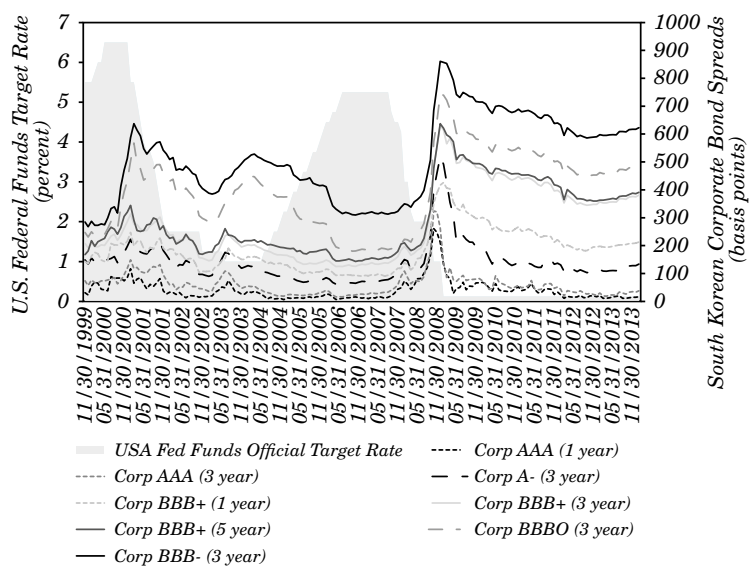

Source: Asian Development Bank, Asian Bonds Online.

Figure 7. Offshore U.S. Dollar Bank Credit and Offshore U.S. Dollar Debt

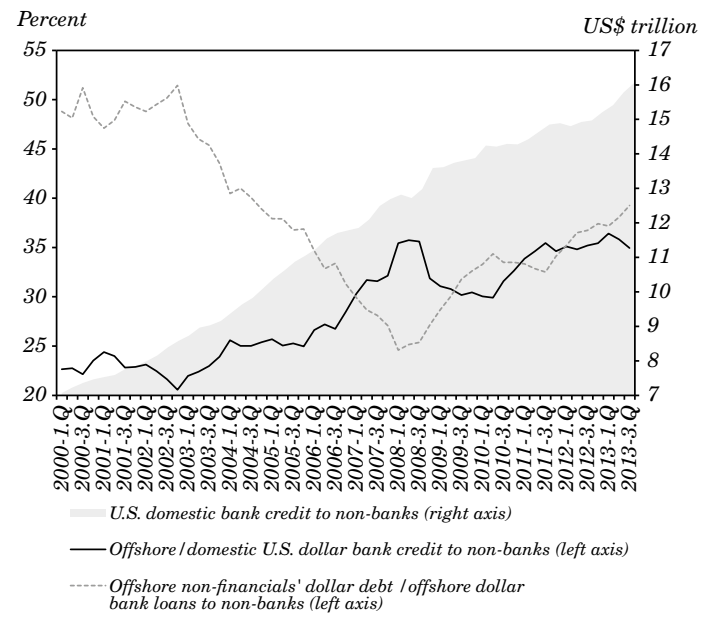

Source: BIS, Global Liquidity Indicators. 
Thus, more than a third of global dollar lending by banks to nonbanks now takes place outside U.S. borders. Alongside offshore dollar bank credit, there is also significant offshore issuance of dollar debt securities by non-financial borrowers. While such issuance stood at about half of offshore dollar borrowing from banks by non-banks in 2000 , the ratio fell sharply up to the GFC as international banking expanded in an environment of low interest rates. The GFC then caused a contraction in bank lending everywhere. More recently, however, offshore dollar bank lending and debt issuance have begun to expand in tandem, with debt issuance rising especially rapidly after the crisis as a result of low long-term dollar interest rates following the Fed's unconventional operations (McCauley, McGuire and Sushko, 2014).

Foreign currency credit presents another transmission channel, most importantly for shocks originating in U.S. financial markets. The effective cost of borrowing in dollars, if those are swapped into domestic currency, is still the domestic interest rate if covered interest parity applies, and a shortage of funding for covered interest arbitrage (as in Ivashina, Scharfstein and Stein, 2012) will only raise the cost of covered dollar borrowing. ${ }^{25}$ However, there are channels through which the interest rate on dollar loans and the loans' availability can directly affect credit flows in economies outside the U.S.

Domestic residents who hedge foreign-currency borrowing will still effectively face the domestic interest rate if covered interest parity holds. However, some may engage in unhedged carry trades, either because they are financially unsophisticated or believe (perhaps wrongly) that domestic currency depreciation is very unlikely. Under this scenario, a fall in the cost of unhedged foreign borrowing will be expansionary in the short run, though possibly highly contractionary later in the event that significant currency depreciation does occur.

More generally, the heavy participation of global non-U.S. banks in intermediating U.S. dollars creates a potent channel for U.S. monetary and financial developments to influence their balance sheets and lending activities, including domestic and foreign lending denominated in dollar currencies. In other words, shocks to the nondollar component of an international bank's balance sheet are bound

25. Munro and Wooldridge (2012) argue, however, that domestic borrowers can overcome some financial frictions by borrowing in foreign currency and swapping the proceeds into domestic currency. 
to spill over to the rest of the balance sheet. For example, a decline in dollar funding rates is likely to raise banking profits, spurring asset expansion across all currencies. The GFC provided vivid examples of negative effects of dollar funding disruptions on non-U.S. banks. Not only non-U.S. banks, but also non-U.S. non-bank dollar borrowers, whether they borrow from banks or in capital markets, may feel effects of changes in dollar interest rates or dollar funding conditions.

\subsection{Implications}

A country that pegs its exchange rate to the dollar and has open capital markets will import U.S. monetary policy. While a flexible exchange rate allows the country to control inflation independently, as in Woodford's (2010) exposition, monetary policy has additional objectives, and globalization might worsen the tradeoff between these and inflation. Some of these are related to the exchange rate, where big changes could have adverse effects on financial stability or internal resource allocation. Even with exchange-rate flexibility, the influence of monetary policy over long-term interest rates could be reduced compared to a closed economy. Spillovers may be easy to absorb when countries throughout the world face common shocks, but less so when their positions are asymmetric, as was the case in the years immediately following the GFC.

Policy rates of interest are central to financial conditions, and induce portfolio shifts toward EMEs, but other aspects of advanced economy financial conditions can spill across borders to EMEs in the form of incipient or actual net capital flows, and gross flows. These factors potentially have substantial impacts on exchange rates, asset prices, and credit volumes, and likewise on economic activity, inflation, and financial stability. Given the prevalence of dollar credit internationally, movements in U.S. interest rates and financial conditions are likely to be especially important.

\section{EvidenCE ON INTEREST RATE INDEPENDENCE}

Because some interest rate independence is a necessary condition for an effective monetary policy aimed at domestic goals, a central empirical question is the correlation between domestic and foreign interest rates, and its relation to the exchange rate regime. This section presents some evidence adding to the findings of previous 
studies by analyzing long-term nominal rates of interest. ${ }^{26}$

A first test, based on approaches of Shambaugh (2004), Obstfeld, Shambaugh and Taylor (2005), and Klein and Shambaugh (2013), investigates the average coherence between a short-term nominal interest rate and a base-country rate in panels of countries. More specifically, consider the regression equation linking country $j$ 's nominal interest rate to the interest rate of base country $b$ :

$$
\Delta i_{j t}=\alpha+\beta \Delta i_{b t}+\boldsymbol{\gamma}^{\prime} \boldsymbol{X}_{j t}+u_{j t}
$$

Above, $\beta=1$ and $\gamma=0$ under a fully credible currency peg. With some exchange rate flexibility, however, there would generally be less than full pass-through of the base rate to the domestic rate, $\beta<1$, and the interest rate might also respond to domestic variables included in the vector $\boldsymbol{X}_{\text {jt }}$ (for example, through a Taylor rule mechanism). Thus, information about the magnitude of $\beta$ and the statistical significance of the coefficient vector $\gamma$ is informative about the degree of monetary independence. In specification (1), differences of interest rates are preferred to levels so as to avoid spurious regression problems.

In general there are at least two concerns in interpreting regression (1). First, if a peg is non-credible, it is possible that elements of $\boldsymbol{X}_{\mathrm{jt}}$ could affect the domestic interest rate by creating realignment expectations. But in that case, we would also expect to see an amplified response of the home interest rate to changes in the base rate, $\beta>1$ (and we would not view this as evidence of monetary independence).

A second concern is with unobserved global shocks that are not fully captured by the included vector $\boldsymbol{X}_{\mathrm{jt}}$. For example, shifts in global risk tolerance or global liquidity might simultaneously move the base and domestic rates in the same direction. Such an omitted variable

26. This section builds on earlier work by Frankel, Schmukler and Servén (2004); Shambaugh (2004); Obstfeld, Shambaugh and Taylor (2005); and Klein and Shambaugh (2013). The general conclusion of these studies (which the evidence in this section supports) is that there is some scope for short-run interest rate independence when exchange rates are flexible. Alternative methodologies attempt to identify exogenous monetary shocks but reach broadly similar conclusions to the previous studies, see Miniane and Rogers (2007) and Bluedorn and Bowdler (2010). In a related vein, Sheets and Sockin (2013) argue that U.S. policy rates strongly influence policy rates of the other major industrial countries, but do so primarily by shifting the arguments in those countries' Taylor rules rather than forcing deviations from Taylor rules. 
would induce a positive correlation between $\Delta \mathrm{i}_{\mathrm{bt}}$ and $\mathrm{u}_{\mathrm{jt}}$, raising the OLS estimate of $\beta$ even under substantial monetary independence. (In this case, the upward biased estimate could be indicating positive transmission of the financial cycle, not of monetary policy.) Alternatively, the global shock might be a generalized shift in portfolio preference between base-country bonds and foreign bonds in general (for example, safe-haven inflows to the base country). In this case $u_{t}$, would tend to have a negative correlation with $\Delta \mathrm{i}_{\mathrm{bt}}$, which would induce a downward bias in the OLS estimate of $\beta$. One way to address the issue is to recognize that different countries have different "natural" base rates-the U.S. dollar for Mexico, the euro for Poland, and the South African rand for Botswana, for example. Accounting for this heterogeneity allows one to control for common time effects in the panel version of (1), and thereby attempt to capture unobserved global shocks.

Several researchers have argued that the Chicago Board Options Exchange's equity option volatility index (VIX) is a useful summary statistic for the state of the financial cycle, lower values being associated with a greater tolerance for risk-taking-including increases in leverage (see Bruno and Shin, 2013; Rey, 2013; among many others). If countries in the sample are matched to their heterogeneous bases, one can enter the percent change in the VIX as an independent variable in the regressions, rather than time fixed effects. This yields an alternative way to control for shocks to the global cycle that potentially move national and base interest rates simultaneously. If the change in the VIX is a stand-in for global shocks that cause global interest rates to move up or down in concert, then adding the VIX should reduce the estimated coefficient $\hat{\beta}$ in (1). On the other hand, VIX movements could be more highly correlated with portfolio shifts between advanced and emerging markets-the waves of capital flow into or out of the developing world discussed by Calvo, Leiderman, and Reinhart-and in that case, we should expect $\hat{\beta}$ to rise when the VIX change is added as a regressor.

To gauge the additional autonomy loss due to pegging, I will use the interactive specification

$\beta=\beta_{0}+\beta_{1} \times P E G$,

where $P E G$ is an indicator variable.

A second type of test, following Frankel, Schmukler, and Servén (2004) and Obstfeld, Shambaugh, and Taylor (2005), considers dynamic adjustment to a long-run levels relationship between home 
and base-country interest rates. To this end, I will estimate country- $j$ specific equations of the form:

$\Delta i_{j t}=\sum_{p=1}^{P} \rho_{p} \Delta i_{j t-p}+\sum_{q=0}^{Q} \beta_{q} \Delta i_{b t-q}+\sum_{q=0}^{Q} \boldsymbol{\gamma}_{q}^{\prime} \Delta \boldsymbol{X}_{j t-q}+\theta\left(i_{j t-1}-\xi i_{b t-1}-\boldsymbol{\omega}^{\prime} \boldsymbol{X}_{j t-1}\right)+u_{j t}$.

In estimating (3), I do not pool over $j$ because of the likelihood of heterogeneous dynamics across economies. In specification (3), the coefficient $\xi$ is the long-run levels relationship between the home and base interest rate, and $-\theta$ is the adjustment speed toward that relationship. We would expect $\xi$ to be in the neighborhood of 1 , with $-\theta$ an inverse measure of the scope for departure from the long-run relation.

Table 1 reports the result of estimating specification (1) as a pooled or panel regression using my full sample of countries $(22$ advanced, other than the U.S. and 34 emerging/developing, dictated by data availability). ${ }^{27}$ None of the specifications will include country fixed effects, on the grounds that a steady positive or negative country-specific nominal interest rate trend is implausible in my data; however, some will include time effects motivated by the possibility of unobserved global shocks that induce higher interest rates everywhere. The results in table 1 provide a very crude first pass that accounts for neither exchange-rate regime nor level of development. Nonetheless, the findings display several regularities that prove robust to more nuanced cuts in the data.

Columns (1)-(4) report regressions of short-term nominal interest rate changes (SR) on the short rate change in a base country, whereas columns (5)-(8) do the same for long-term nominal interest rates (LR). Also included in the $\boldsymbol{X}$ variables that enter equation (1) are current values and lags of the change in real GDP and the change in CPI inflation, where I use the Bayesian Information Criterion to determine the number of lags to include - up to a maximum of six. ${ }^{28}$ Thus, the observations are at quarterly frequency. The short-term interest rate is the quarterly average of end-of-month rates on 90-day or 91-day government securities; the long-term rate is the quarterly average of end-of-month rates on 10-year government bonds.

27. Data coverage is detailed in an appendix. Even where longer data series are available, I generally estimate over the period starting around 1990 so as to capture the regularities that apply during the recent period of high and growing financial globalization. See Klein and Shambaugh (2013) for analysis of longer time series.

28 . To save space, I do not report coefficients on these auxiliary variables. 


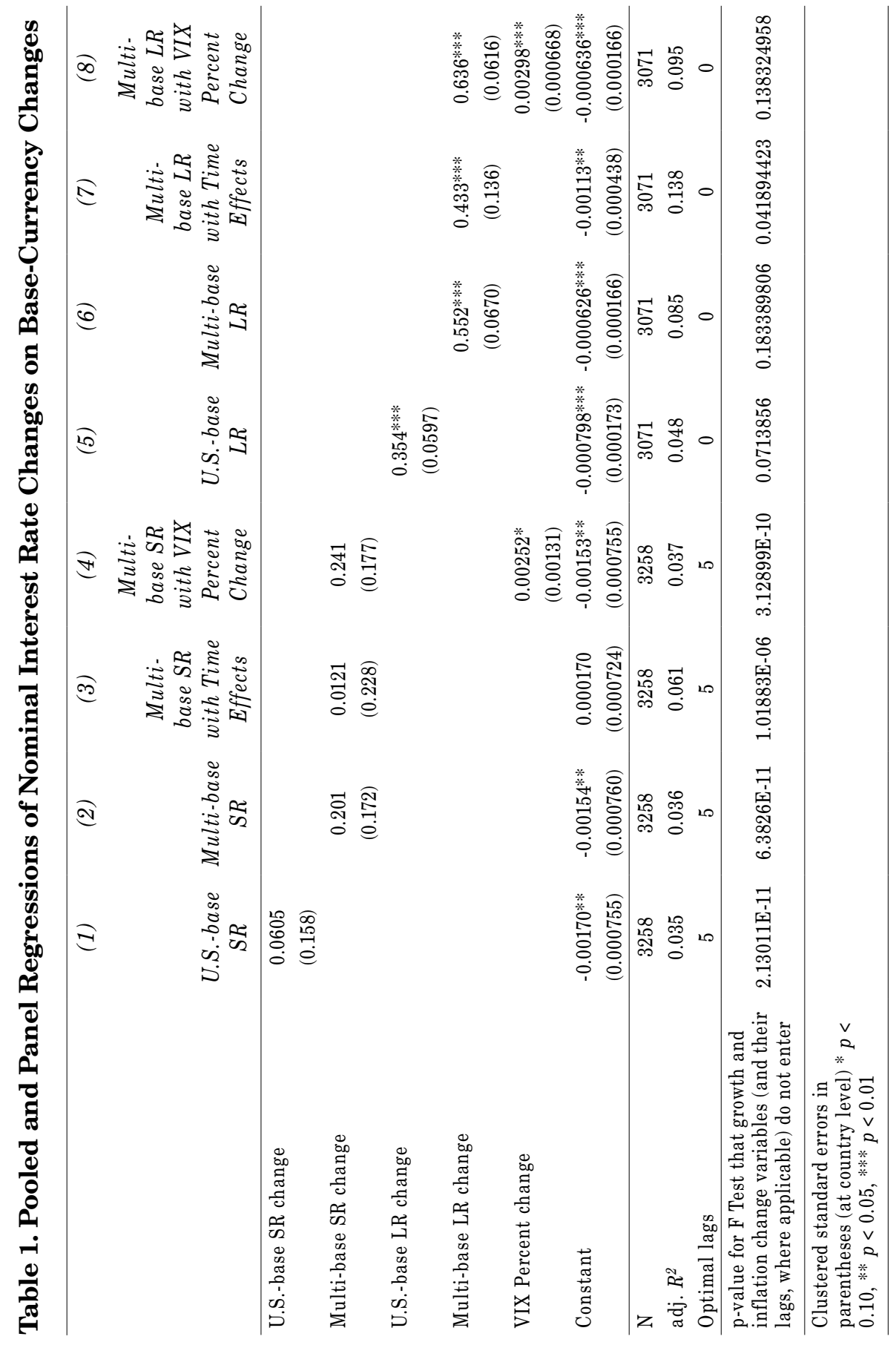


Column (1) assumes that the U.S. dollar is the base currency for all other countries, and the estimated coefficient on its interest rate turns out to be tiny and statistically insignificant. Once countries are matched to more appropriate base currencies-in the currencies they are most likely to shadow, however-the estimated coefficient better than triples (to 0.201 ) but it remains rather small, and insignificant. In column (3), adding time effects to the column (2) specification reduces the coefficient, as one would expect when the time effect captures global shocks that induce positive covariation in policy rates of interest. Adding the change in the VIX in column (4) raises $\hat{\beta}$ compared to column (2), but not significantly so. However, the change in the VIX itself is significant at the 10 percent level, with a rise in the VIX raising the domestic interest rate. The results are consistent with the view that reductions in global-risk aversion are associated with portfolio shifts toward EMEs.

In all column (1)-(4) regressions there is overwhelming evidence for a role of lagged changes in domestic output and inflation-effects that would be absent were domestic interest rates determined entirely by nominal arbitrage without exchange-rate variability. These results, together with the low estimates $\hat{\beta}$, are compatible with substantial interest-rate independence at the short end.

Columns (5)-(8), which analyze long-term rates, present a starkly different picture. In column (5), which takes the U.S. dollar as the universal base, the coefficient on the U.S. bond rate change is significantly different from zero at the 1 percent level, though significantly below 0.5 . However, once countries are matched to their most natural base currencies, the coefficient rises above 0.5, remaining highly significant. Time effects lower the coefficient (to 0.433 ), but the change is not significant and the new slope estimate remains significant at the 1 percent level. Finally, adding the VIX change raises $\hat{\beta}$ substantially, and the VIX variable is itself highly significant, suggesting that the global financial cycle is communicated to long-term interest rates. The effect of a change in the VIX is small but precisely estimated for long-term rates. Interestingly, the auxiliary domestic macro variables usually do not enter this regression with very high significance, and the adjusted $R^{2}$ in columns (5)-(8) are uniformly higher than those in columns (1)-(4). The LR picture is one of much less interest-rate independence than in the SR case. 
Table 2 breaks out the role of exchange rate pegs by adding specification (2) to specification (1), thereby interacting the interestrate response with the peg indicator. ${ }^{29}$ For the SR case in the first four columns, positive correlations with the base-currency interest rate change are almost entirely due to being pegged. Adding time effects lowers the estimated SR peg effect somewhat, but leaves it potentially large. Adding the VIX change has little impact compared to column (2). Perhaps surprisingly, the peg interactions are not themselves statistically significant, even at the 10 percent level. It may be that the limited commitment under a de facto peg allows substantial room for interest-rate deviations from the base, at least for some of currencies.

The LR $\hat{\beta}$ s in the last four columns follow the pattern familiar from table 1 . They are reasonably big and very significantly different from zero. While a peg is always estimated to raise the correlation, that result is never statistically significant. It should be noted, however, that because the different base long rates tend to be highly correlated among themselves, adding time effects in this case induces some multicollinearity. As earlier, adding the VIX change raises the estimated coefficient on the base interest rate (both for pegs and nonpegs), and the VIX change itself is highly significant. As in table 1, the auxiliary output and inflation variables are not usually highly significant in the LR regressions of table 2, regardless of the exchange rate regime. (These regressions allow the coefficients on the auxiliary variables to differ as between pegs and non-pegs).

The summary of table 2 is that there is considerable independence at the short end of the term structure apart from pegged exchange rates, whereas long rates remain significantly correlated with those of base-currency countries even in the absence of a peg (although pegs appear to raise the correlation somewhat, compared to non-pegs). As in table 1, given the base long-term rate, the domestic long-term rate appears less responsive to standard domestic macro variables.

29. I adapt, to quarterly data, the de facto currency regime coding method from Klein and Shambaugh (2013) who themselves look at a finer gradation of regimes than just peg or non-peg. See the discussion in the next section. (See the appendix.) I thank Michael Klein and Jay Shambaugh for providing the files underlying their paper. 


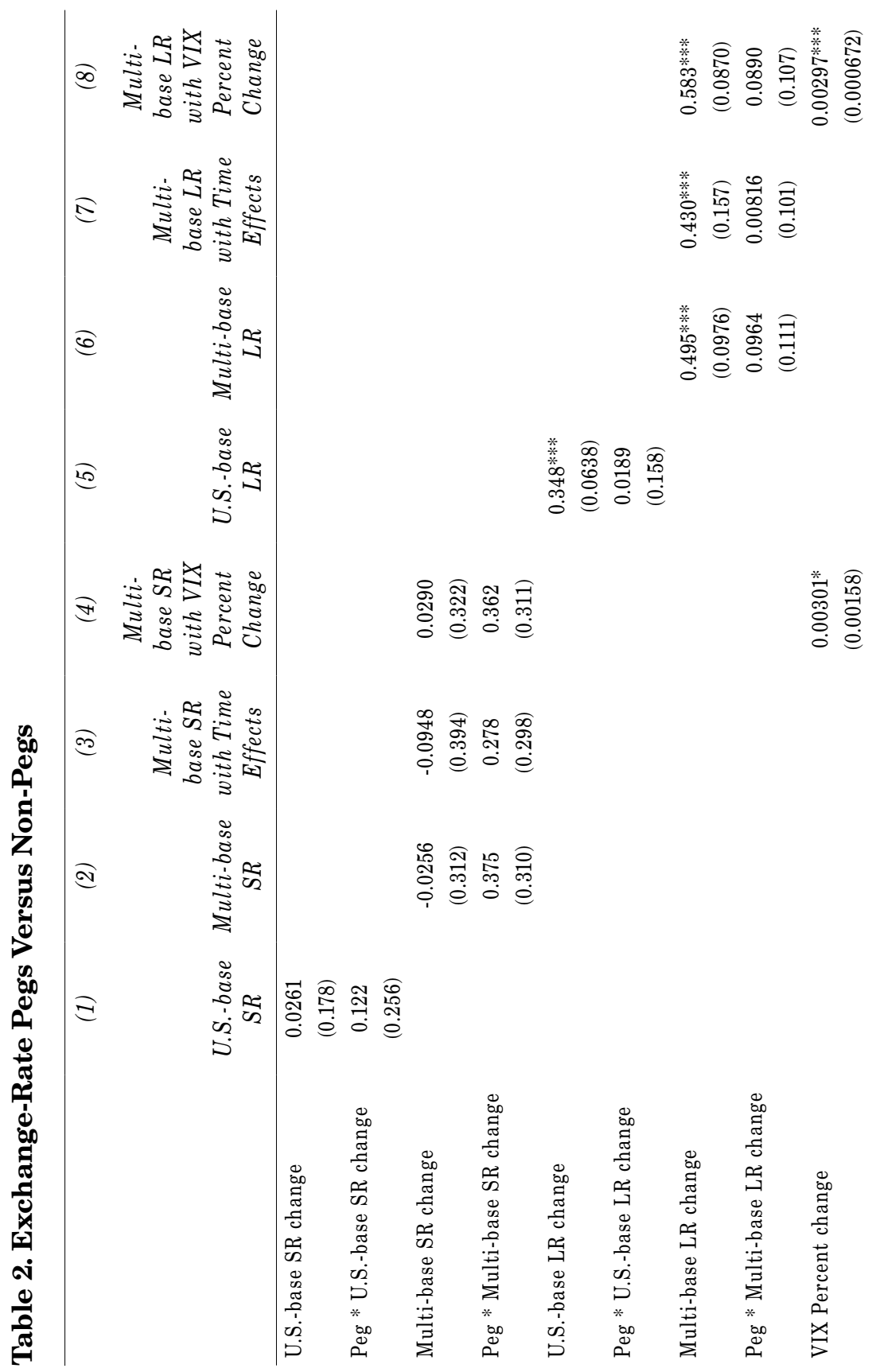




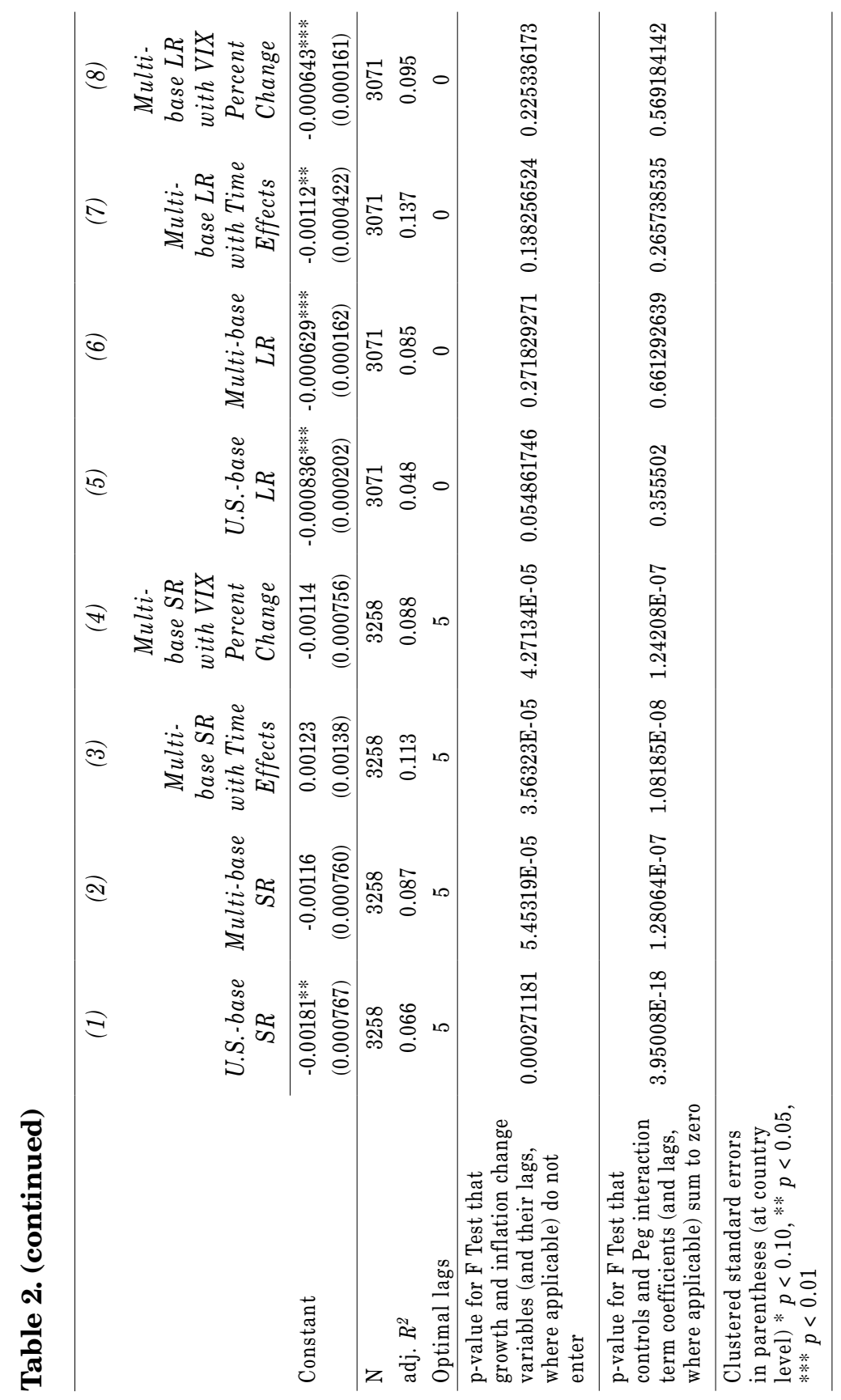


Tables 3 and 4 contrast the results for developing/emerging and advanced economies (with Newly Industrialized Asia placed in the emerging group). Short-term rates for the developing/EME non-pegs appear less tightly linked to base-currency short-rates than for the advanced group of non-pegs, and for the advanced countries, the marginal effect of being pegged is greater for dollar pegs than for pegs in general; although, there is little difference for developing/ EME countries. The time effects regression in column (3) of table 4 suggests that much of the synchronization of advanced short-term rates with base rates is due to common responses to global shocks. Long-term rate coherence with base rates also seems much greater for advanced economies, with quantitatively important pegs only for advanced countries pegged to the U.S. dollar. By and large, the results are not inconsistent with substantial monetary independence in terms of short policy rates, even though the advanced economies move in step to a considerable degree. While the coherence among movements in long-term interest rates being much more pronounced for advanced countries, advanced-country data series on long rates are much longer, and reflect much thicker markets, so the results in table 3, columns (5)-(8), should be interpreted cautiously. To the extent that long-term rate co-movement among advanced countries represents forces of arbitrage, it could capture a weakening of the potency of domestic monetary policies and a channel for monetary spillovers from abroad. A final finding in tables 3 and 4 is the importance of the VIX change for movements in long-term interest rates, given base rate changes for both country groups, but especially for non-advanced economies.

The apparently higher short-term rate independence for developing/emerging economies, compared to advanced economies, could follow from a greater prevalence of capital controls (recall figure 5). As Klein and Shambaugh (2013) document, however, only thoroughgoing and long-standing controls seem effective in conferring greater monetary independence-other things equal.

Turn next to estimation of the dynamic relationship (3). The approach of Pesaran, Shin and Smith (2001), hereinafter PSS, allows for a levels relationship as in (3) between domestic and base rates of interest, even when interest rate levels are stationary. However, different critical regions for test statistics apply depending on whether interest rates are $\mathrm{I}(0)$ or I(1). PSS tabulate the appropriate critical values. Because the data are monthly, the vector $\boldsymbol{X}$ in (3) includes only the level of CPI inflation. 
Tables 5 and 6 report results for short-term and long-term nominal interest rates, respectively, with all countries measured against the U.S. dollar as base currency. The columns labeled "PSS F stat" indicate whether the hypothesis $\theta=\xi=\omega=0$ (i.e., no levels relationship) is rejected at the 5 percent level (indicator $=1$ ) or not (indicator $=0$ ) under the alternative assumptions that the variables in specification (3) are, respectively, I(0) and I(1). Similarly, the columns labeled "PSS T stat" concern the hypothesis $\theta=0$.

As expected, there is considerable heterogeneity across countries, even within broad country groupings. Looking at country-group averages, however, the values of $\xi$ have a central tendency in the neighborhood of 1 for both groups, for both short- and long-term interest rates; although, estimates are much more precise for the advanced countries. Thus, the levels relationship (when it exists) is consistent with long-run equality of nominal interest rates at short and long maturities (up to a constant). The average adjustment speed $\theta$ for long rates is nearly the same for both country groups, implying adjustment half-lives of about 14.6 to 17.5 months. For short-term rates the adjustment speed appears to be quite a bit faster for developing/emerging economies (about a year, as opposed to over two years), though once again, the standard error of estimation is comparatively large. The data seem consistent with the existence of a long-term levels relationship in a good number of cases when the data are $\mathrm{I}(0)$, but generally less so when the data are I(1). It is particularly hard to detect a levels relationship for developing/ emerging short-term rates. It is also very hard to reject the hypothesis $\theta=0$ for those rates.

These averages, as noted, conceal considerable idiosyncrasies, even within Asia. For example, with respect to short-term interest rates, Hong Kong shows unitary long-run coherence with U.S. rates and an extremely rapid adjustment speed (half-life below 4 months). Singapore's adjustment speed is even more rapid, but its estimated $\xi$ is only 0.39 . Malaysia shows both a $\xi$ value of 0.58 , and a slow adjustment speed that implies an estimated half-life of about a year and a half. The results for long-term rates are, on the whole, similar.

The overall impression is that nominal interest rates trend strongly with U.S. rates in the long run, in both country groups, but there is usually considerable medium-run scope for interest-rate independence. As before, however, the possibility of unobserved global shocks to interest rates bedevils the interpretation of these results. 


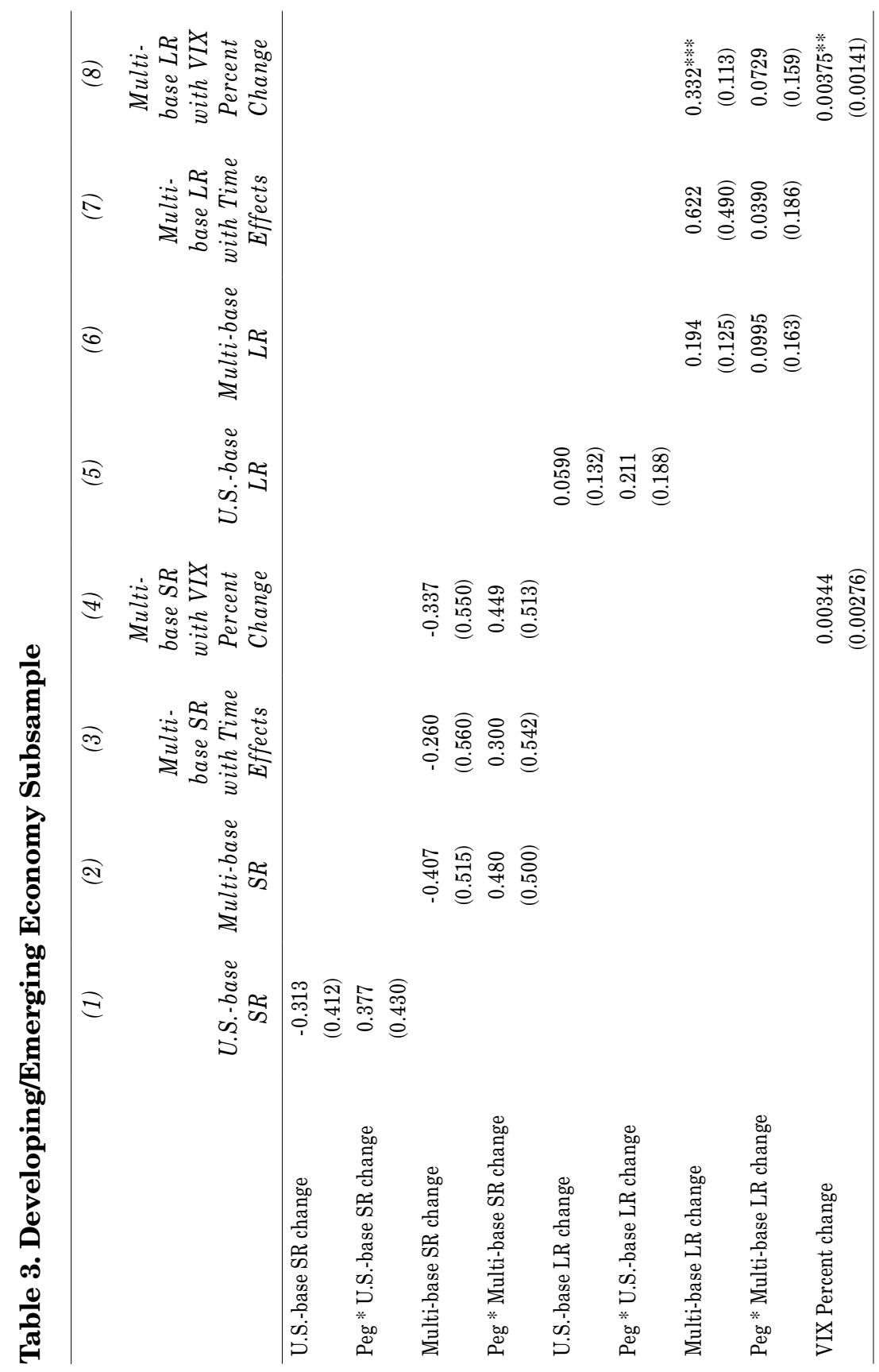




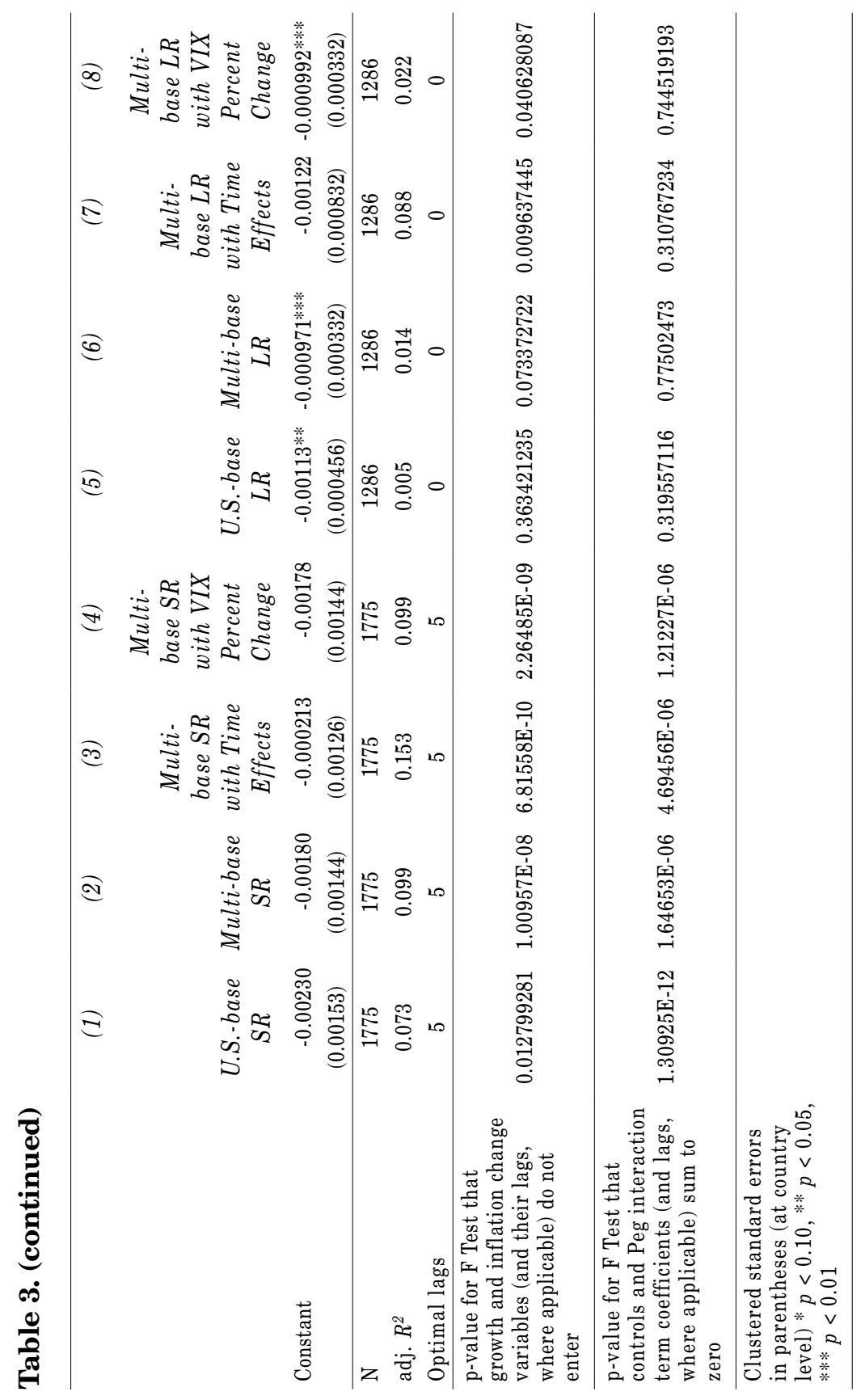




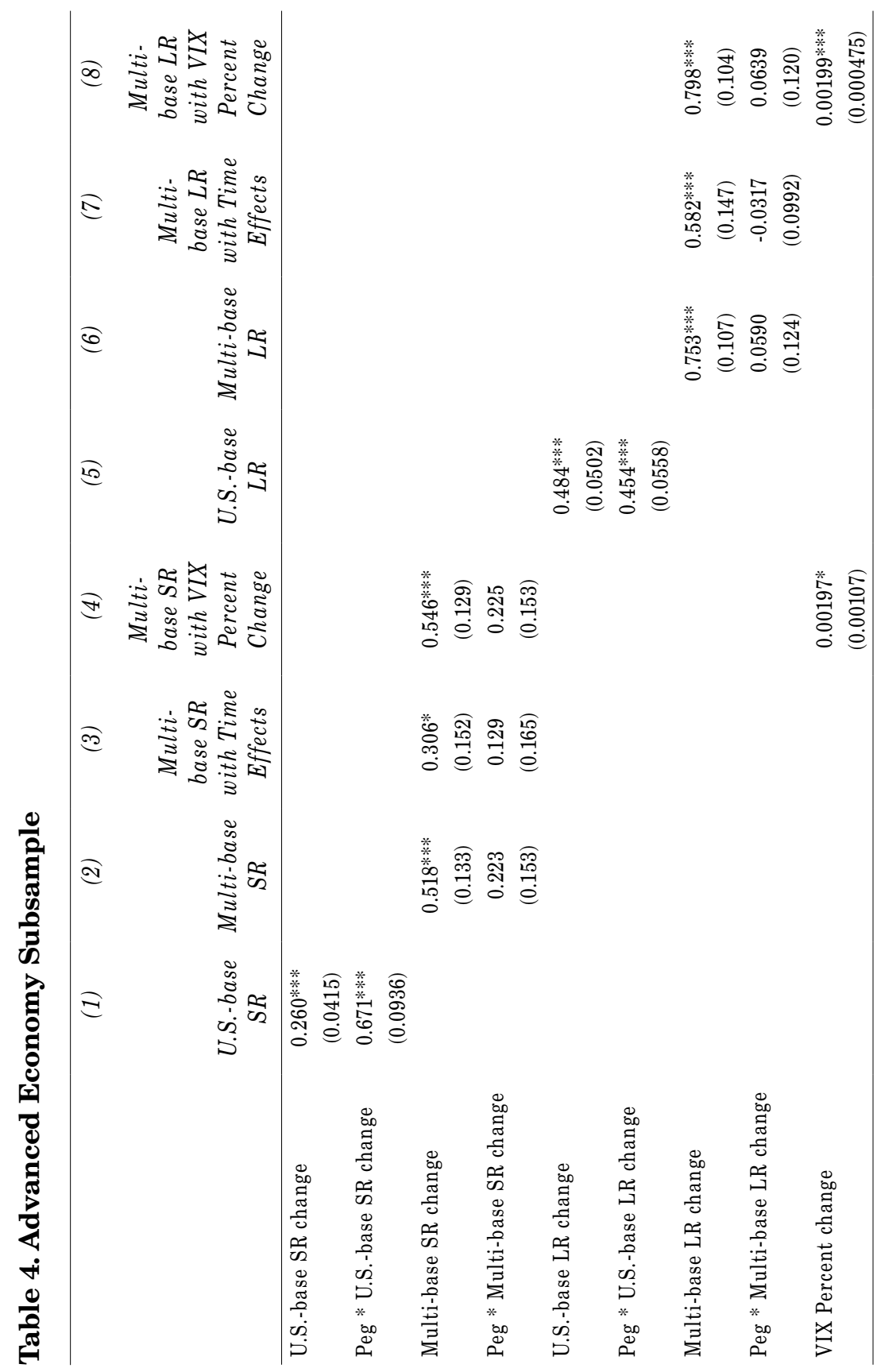




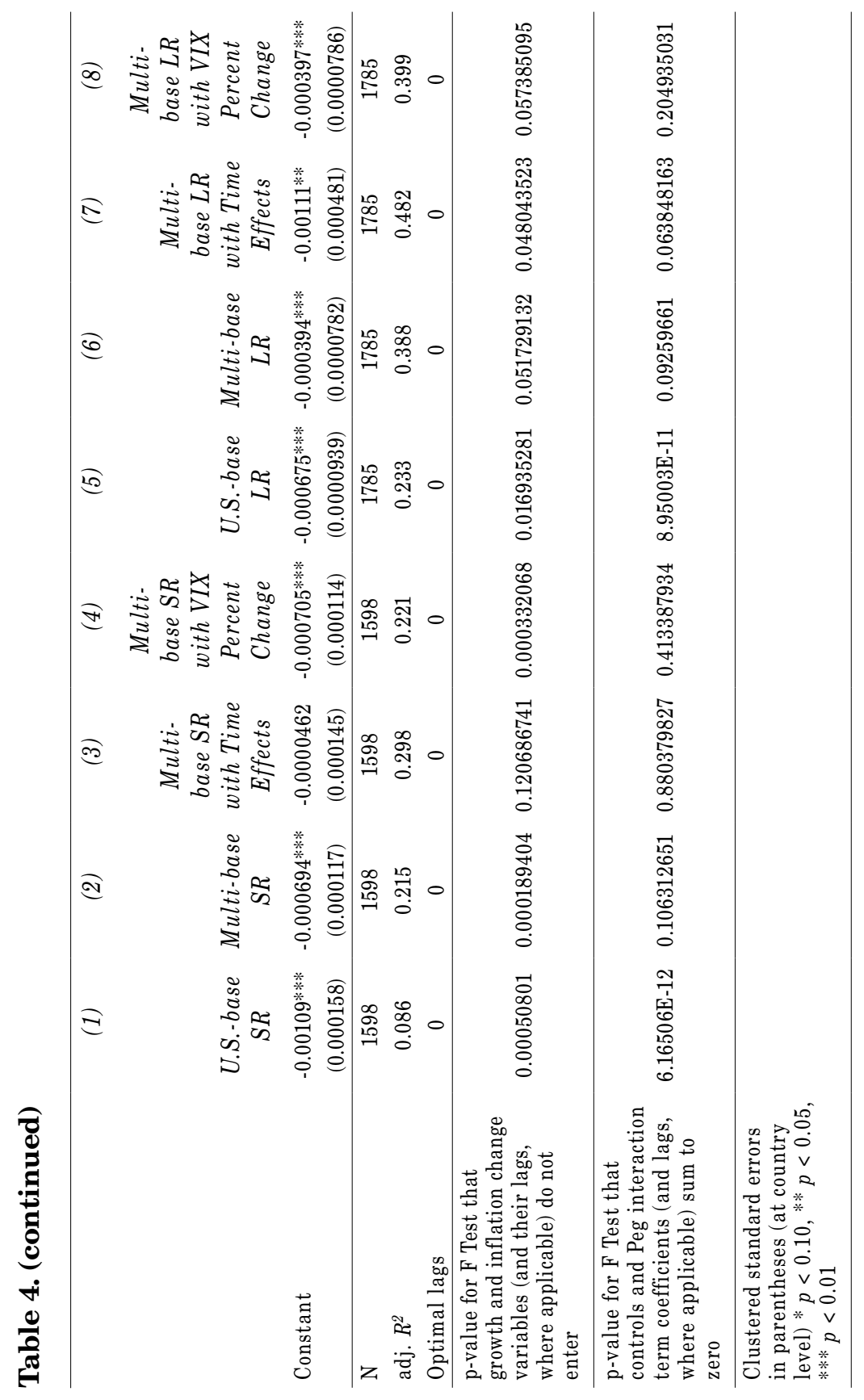




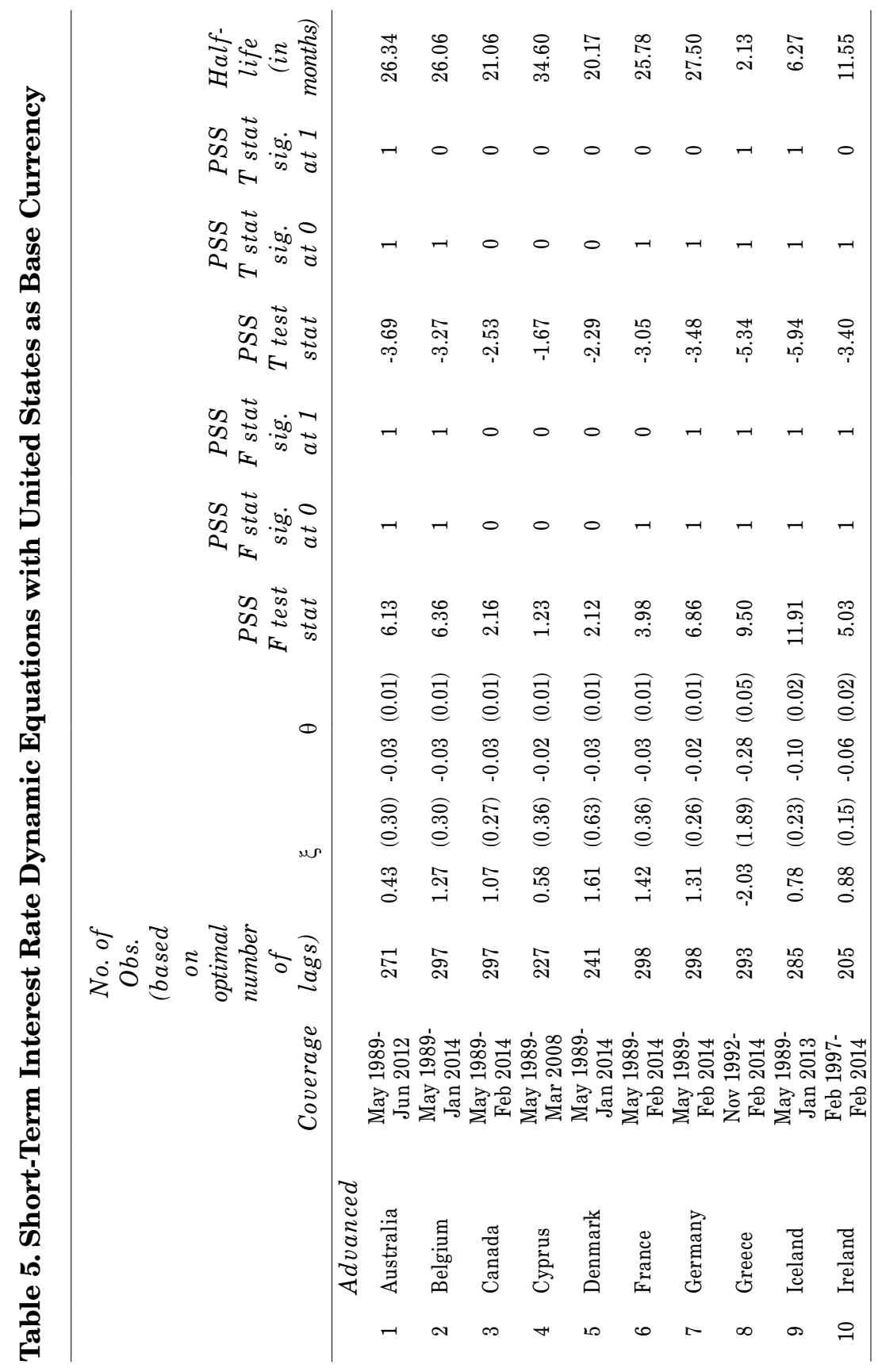




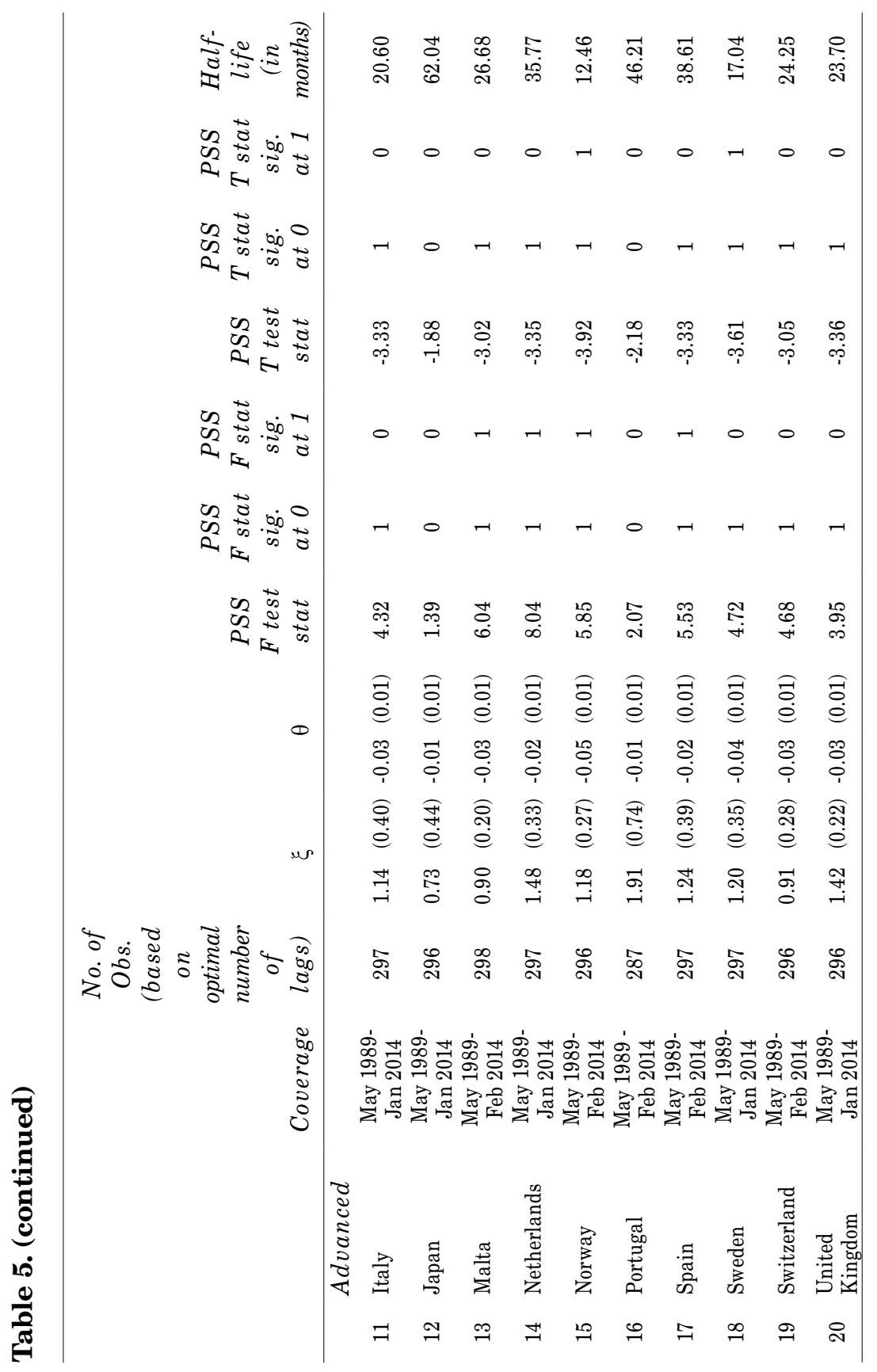




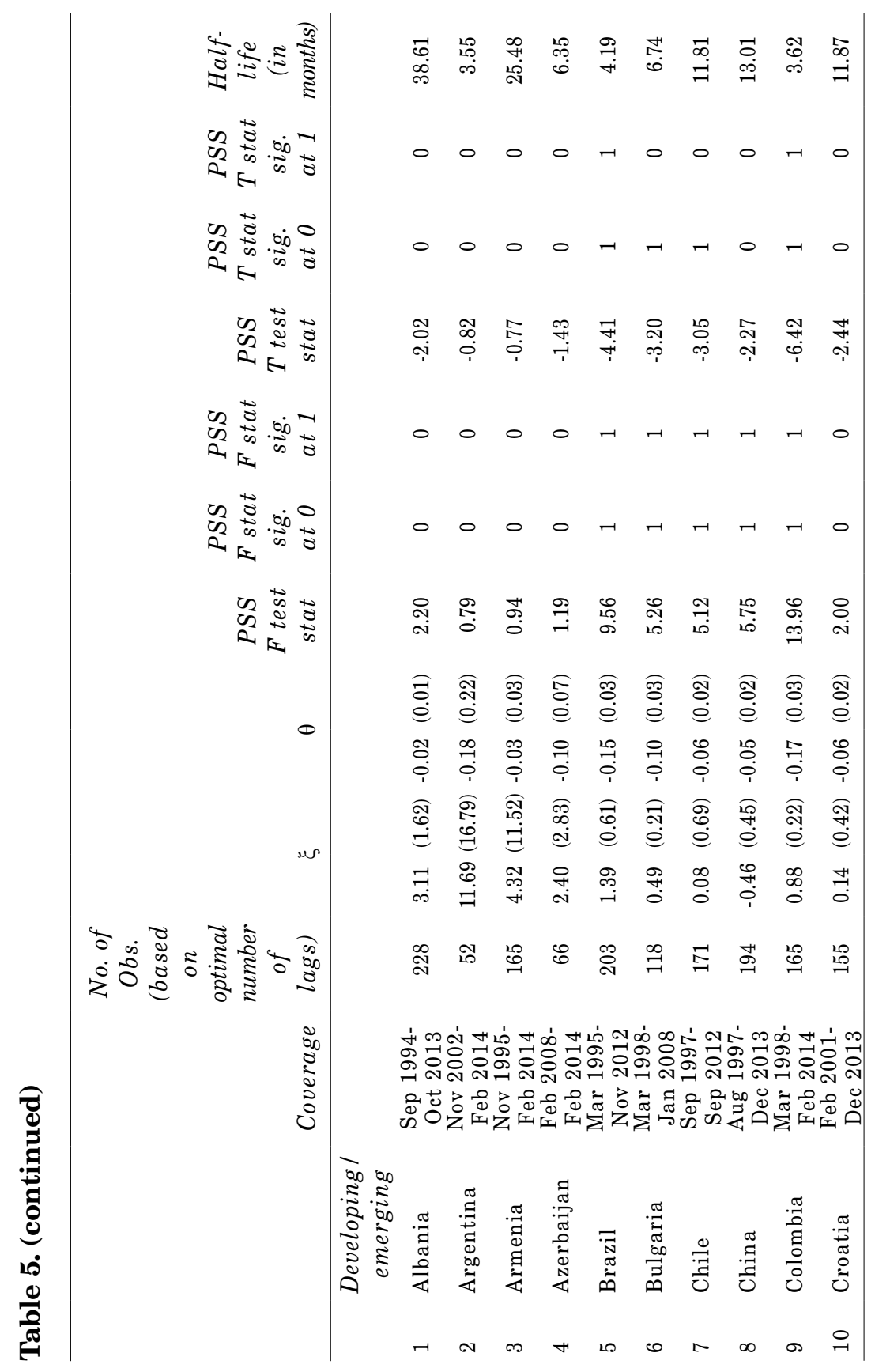




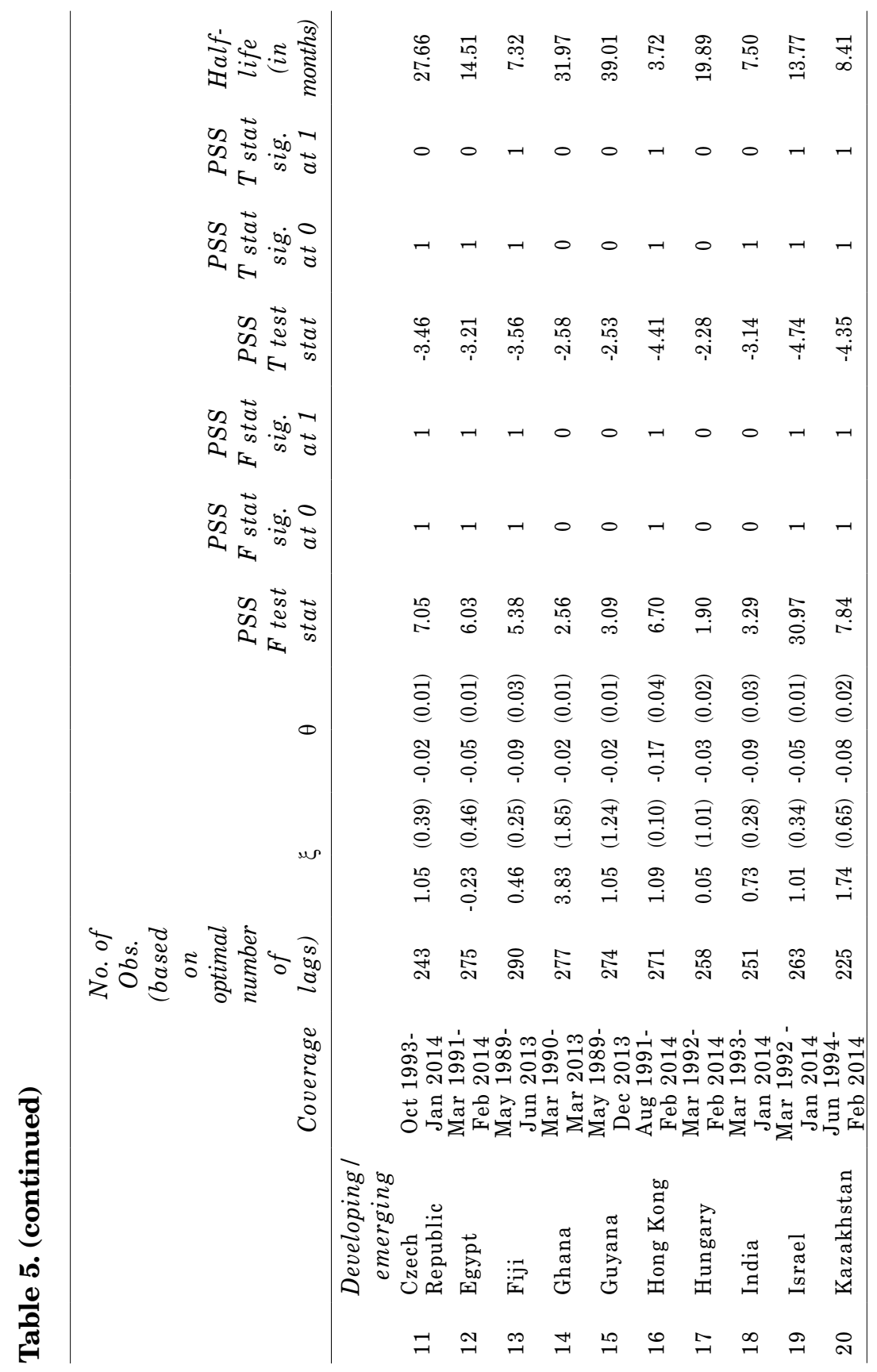




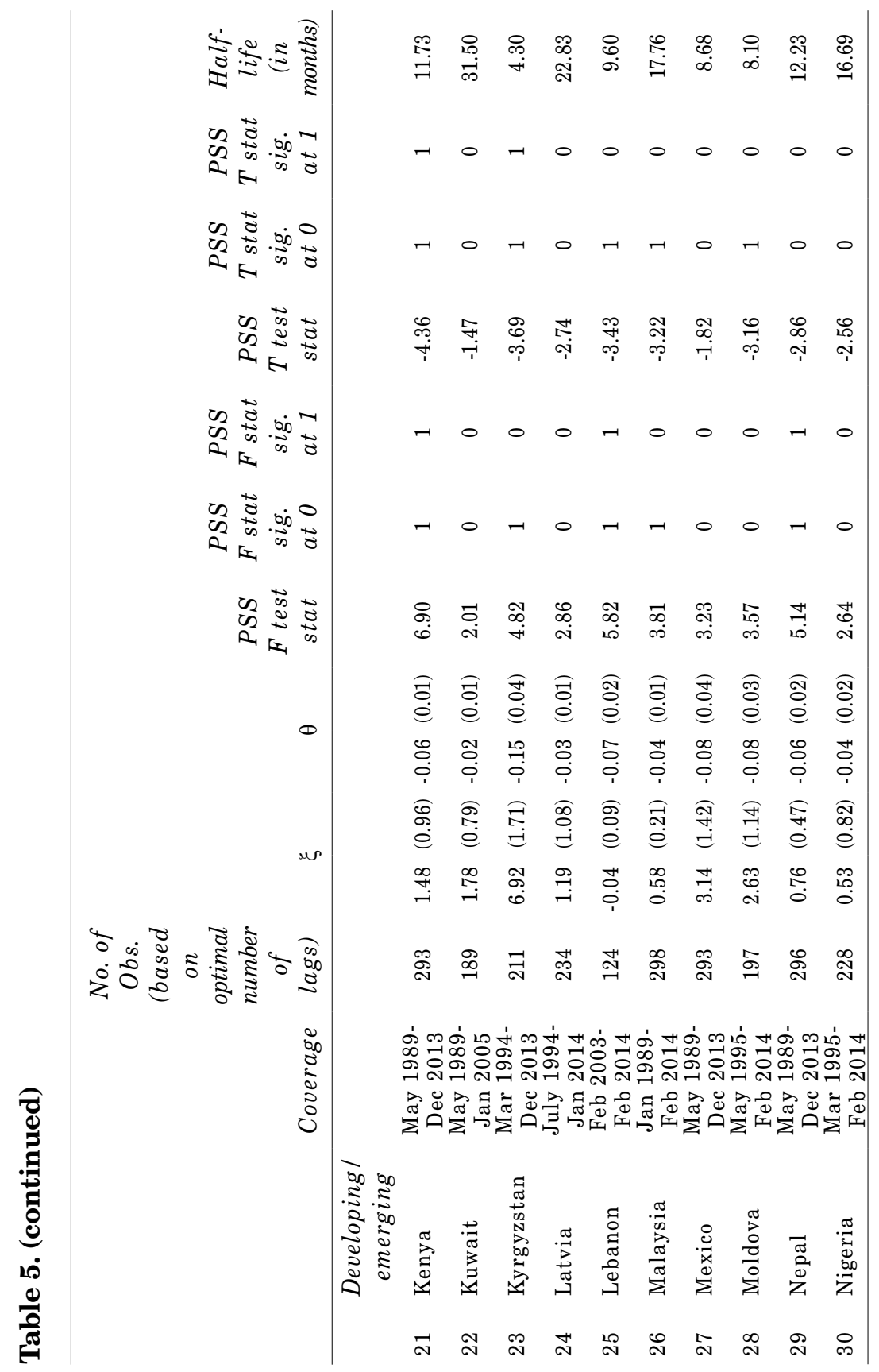




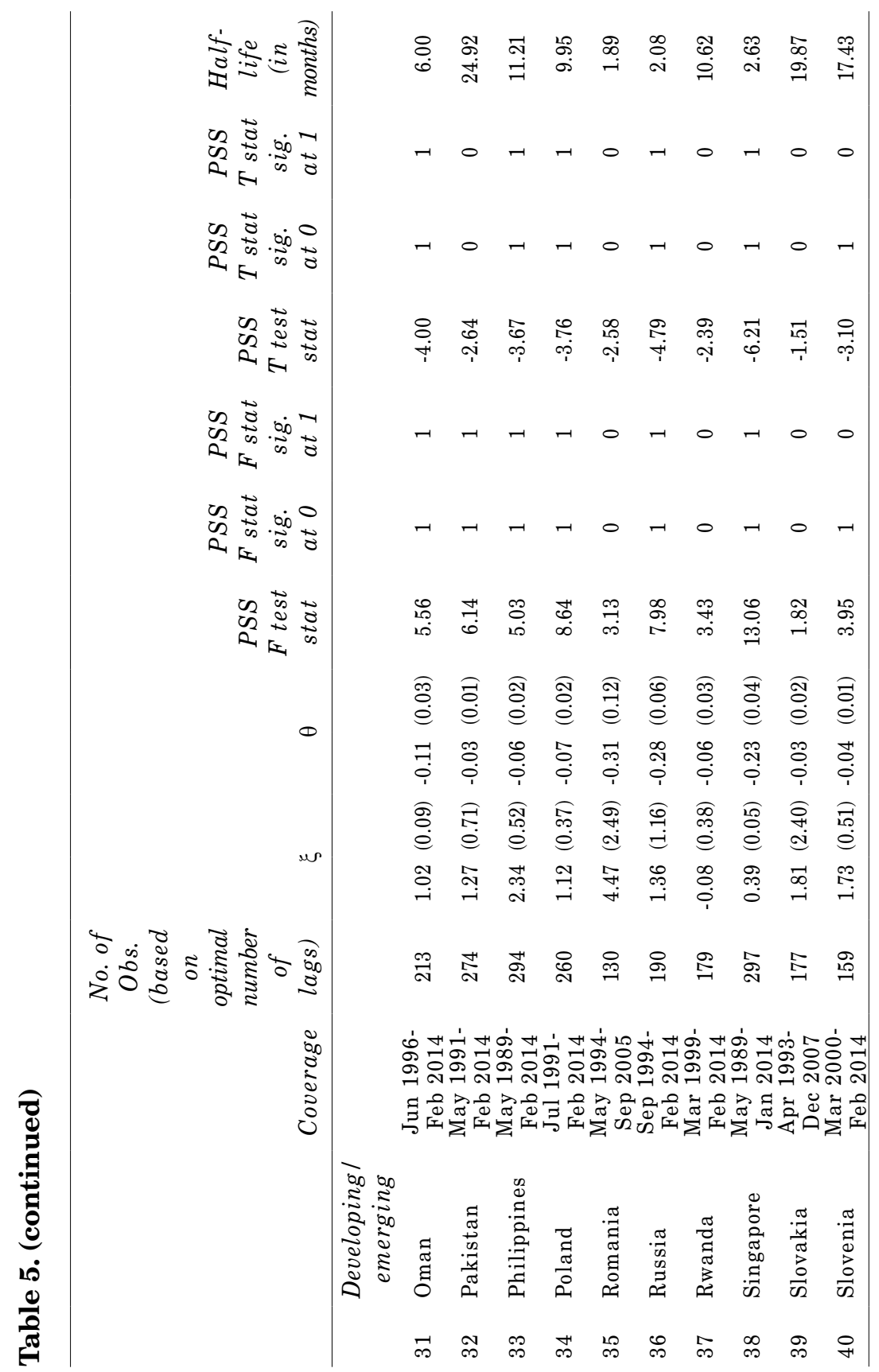




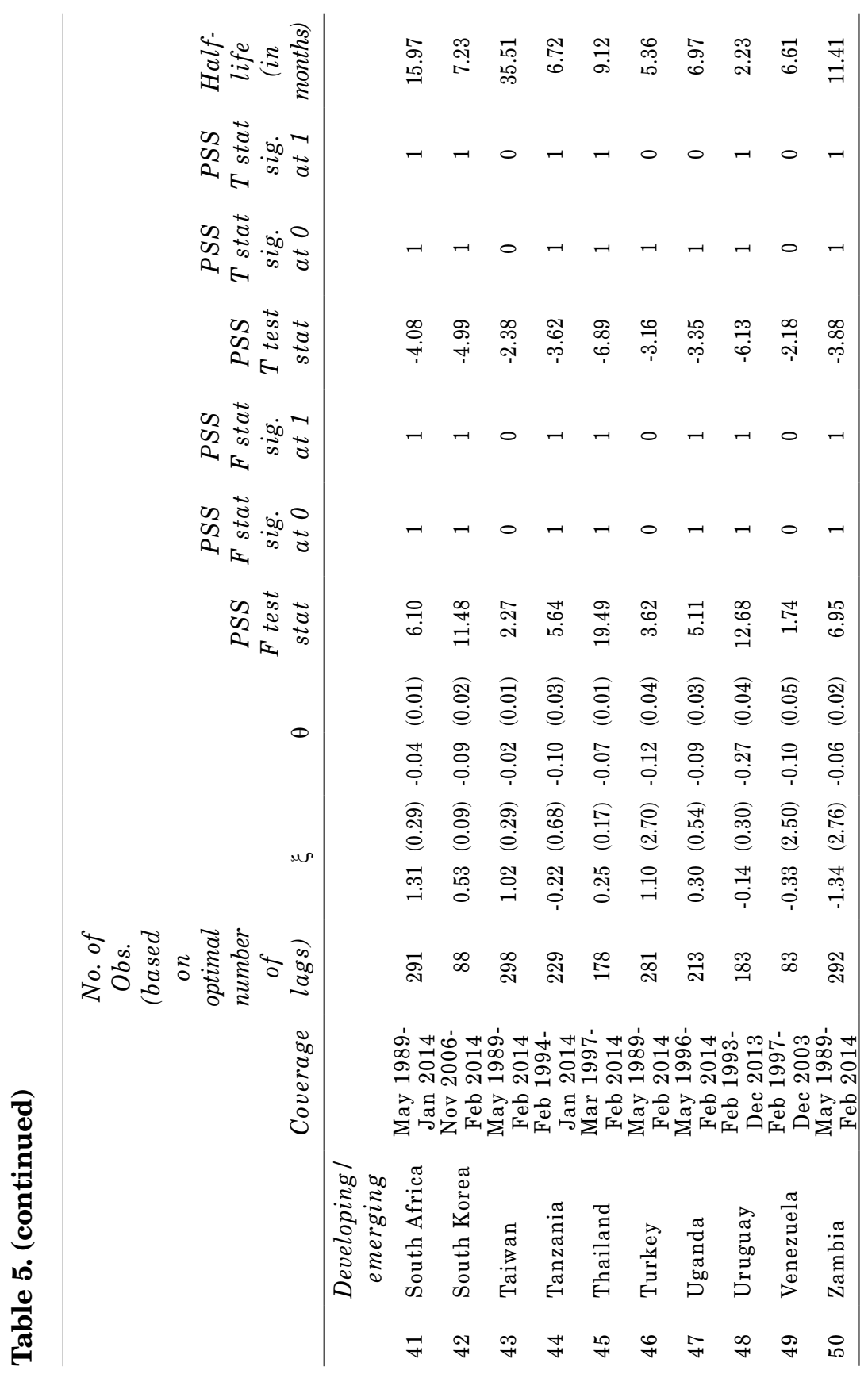




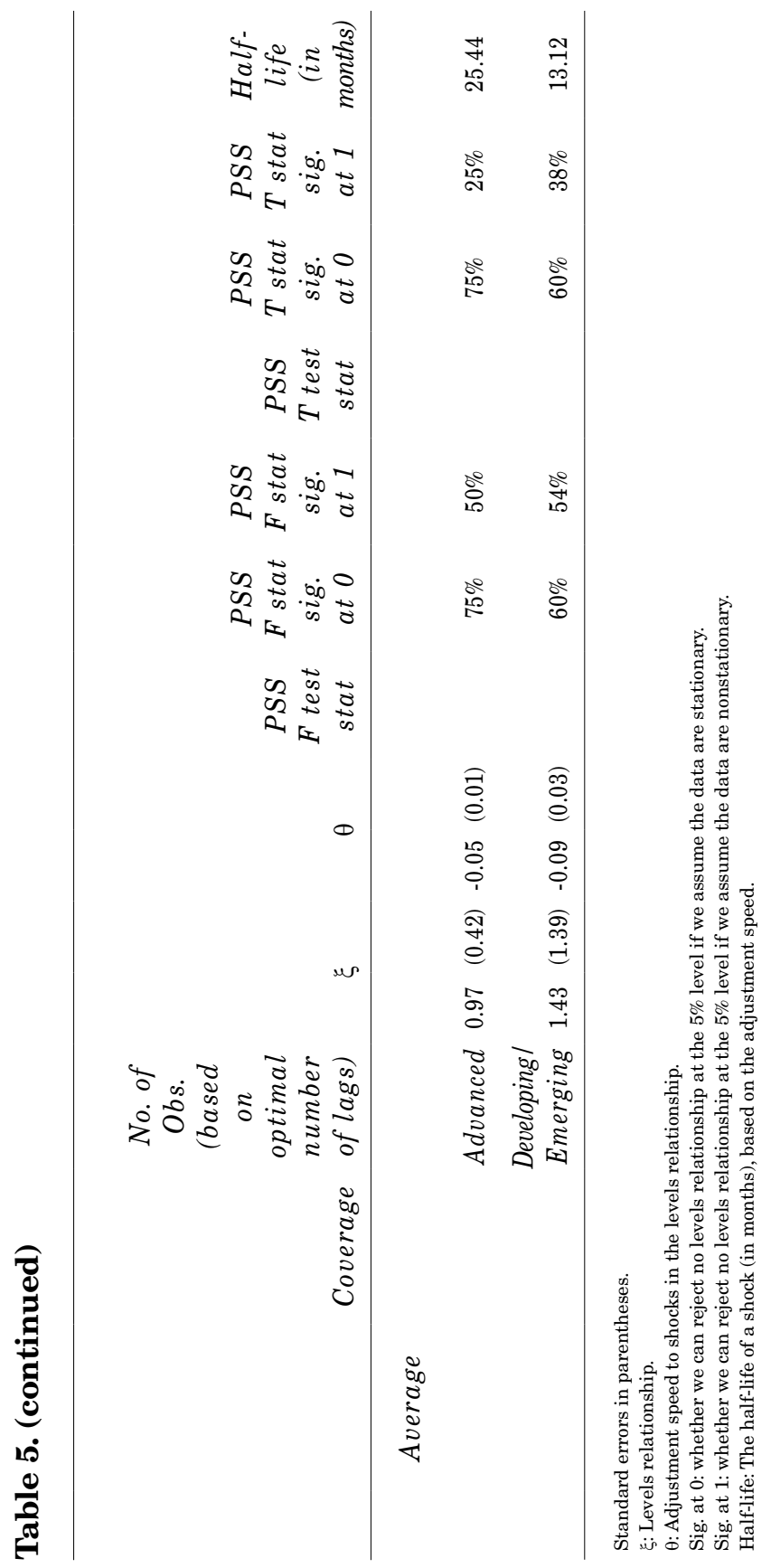




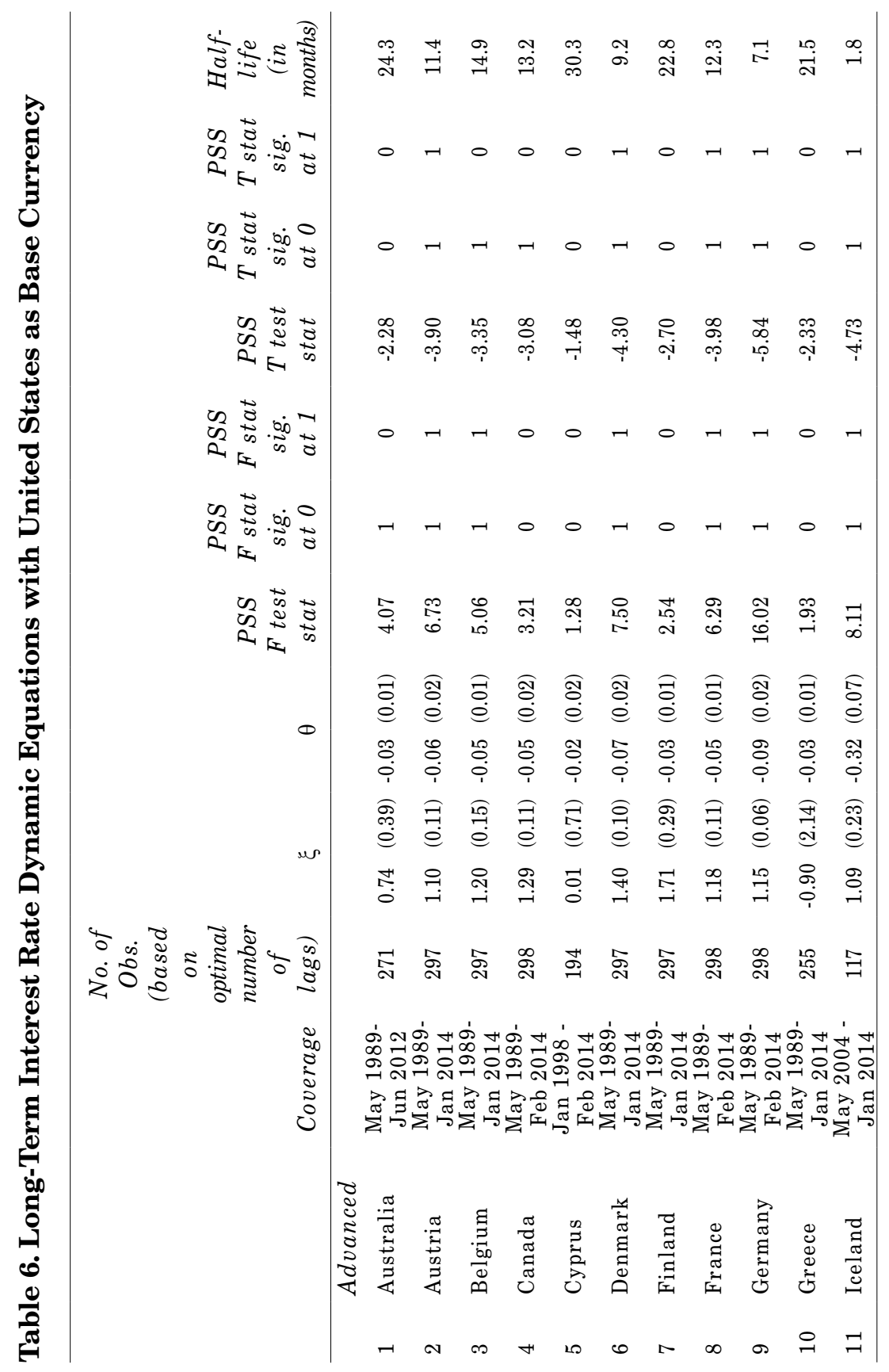




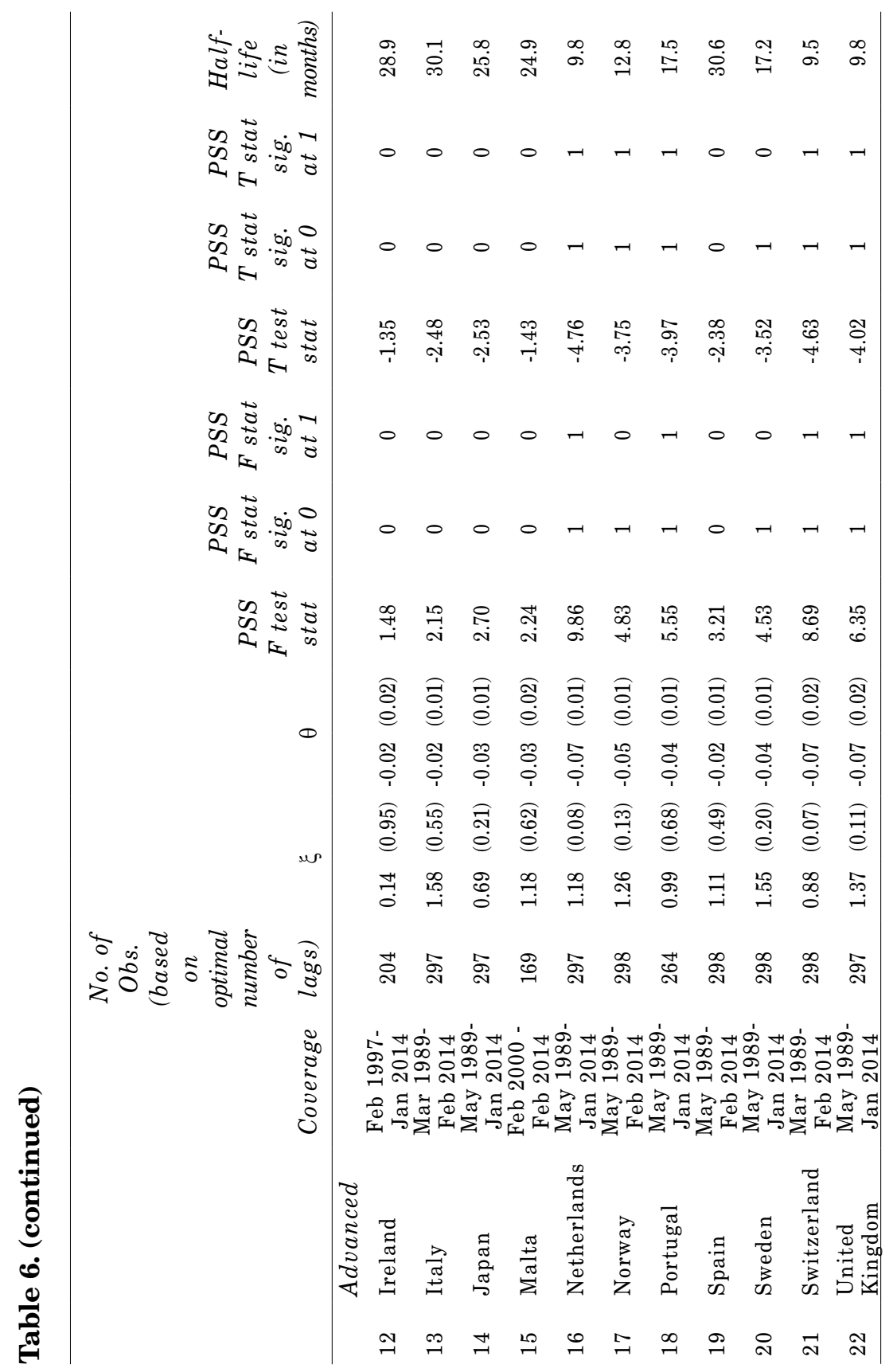




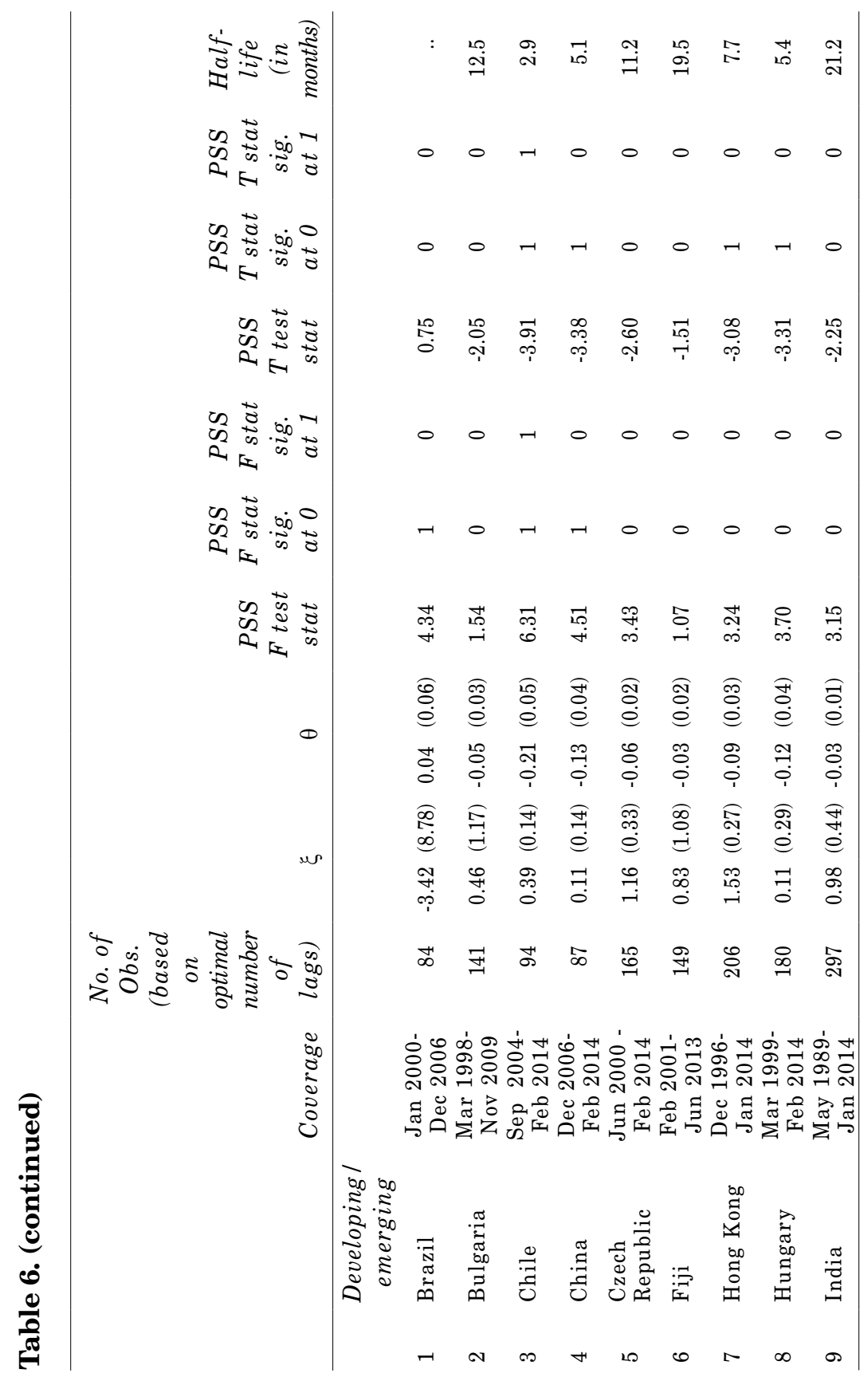




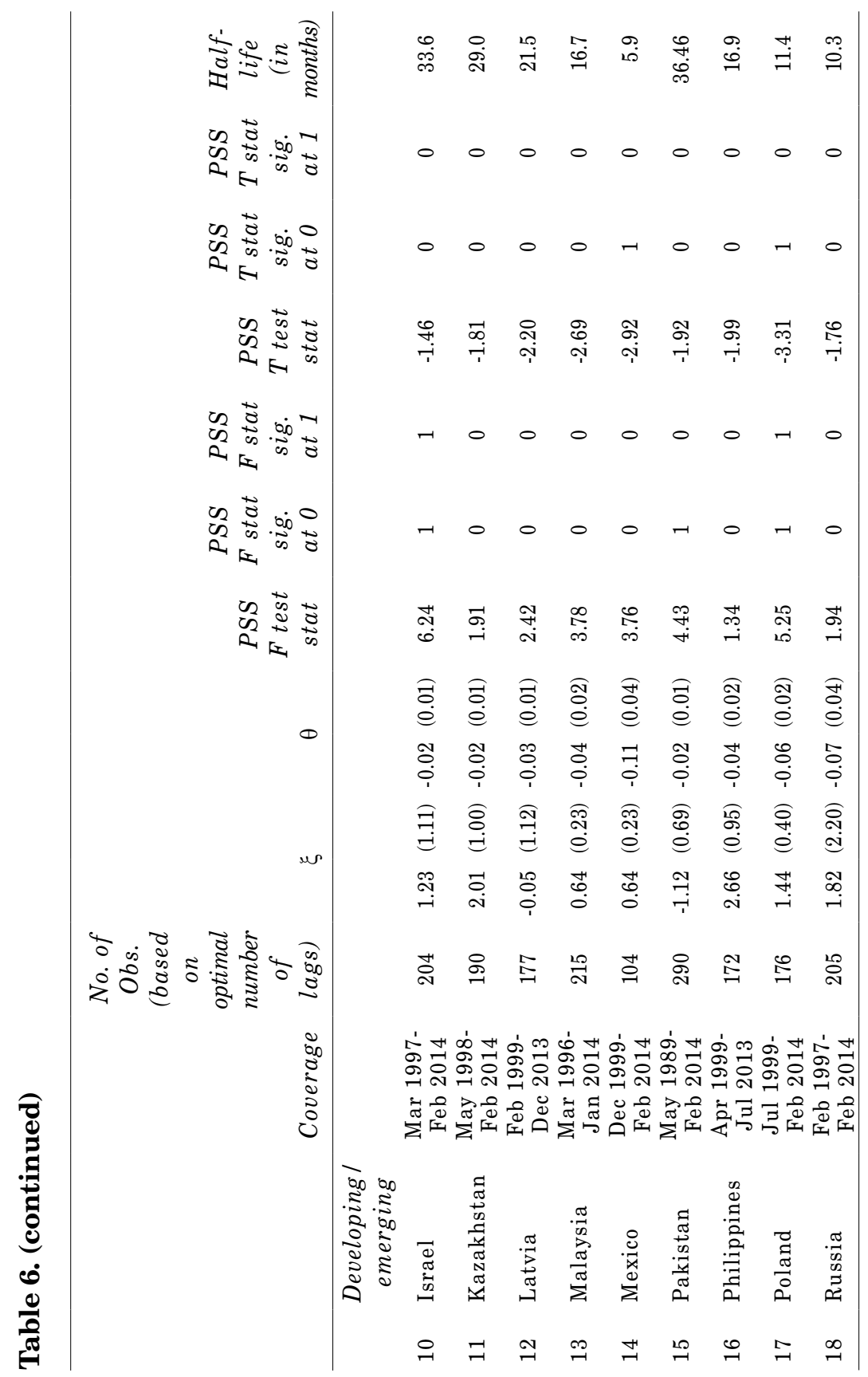




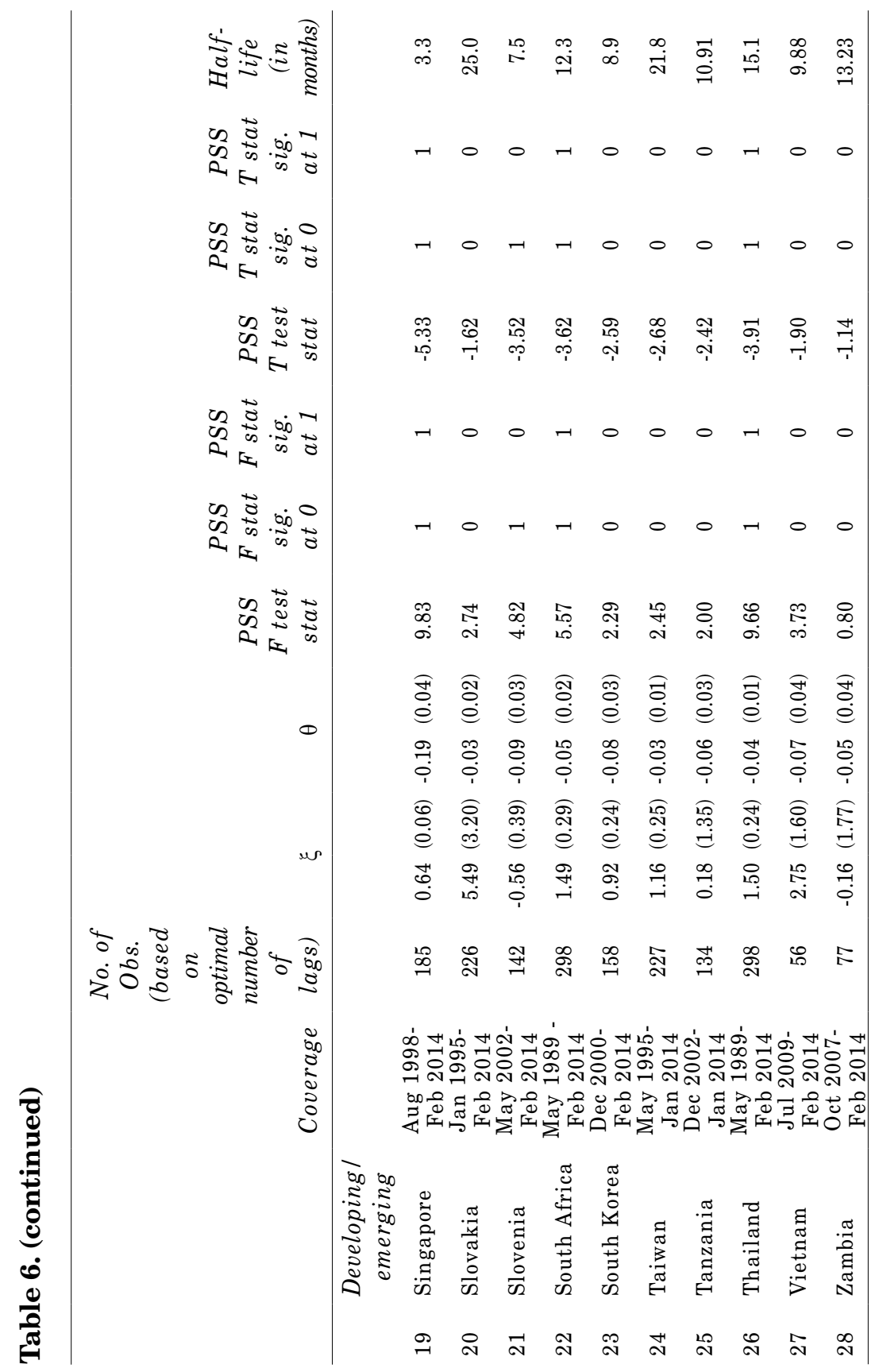




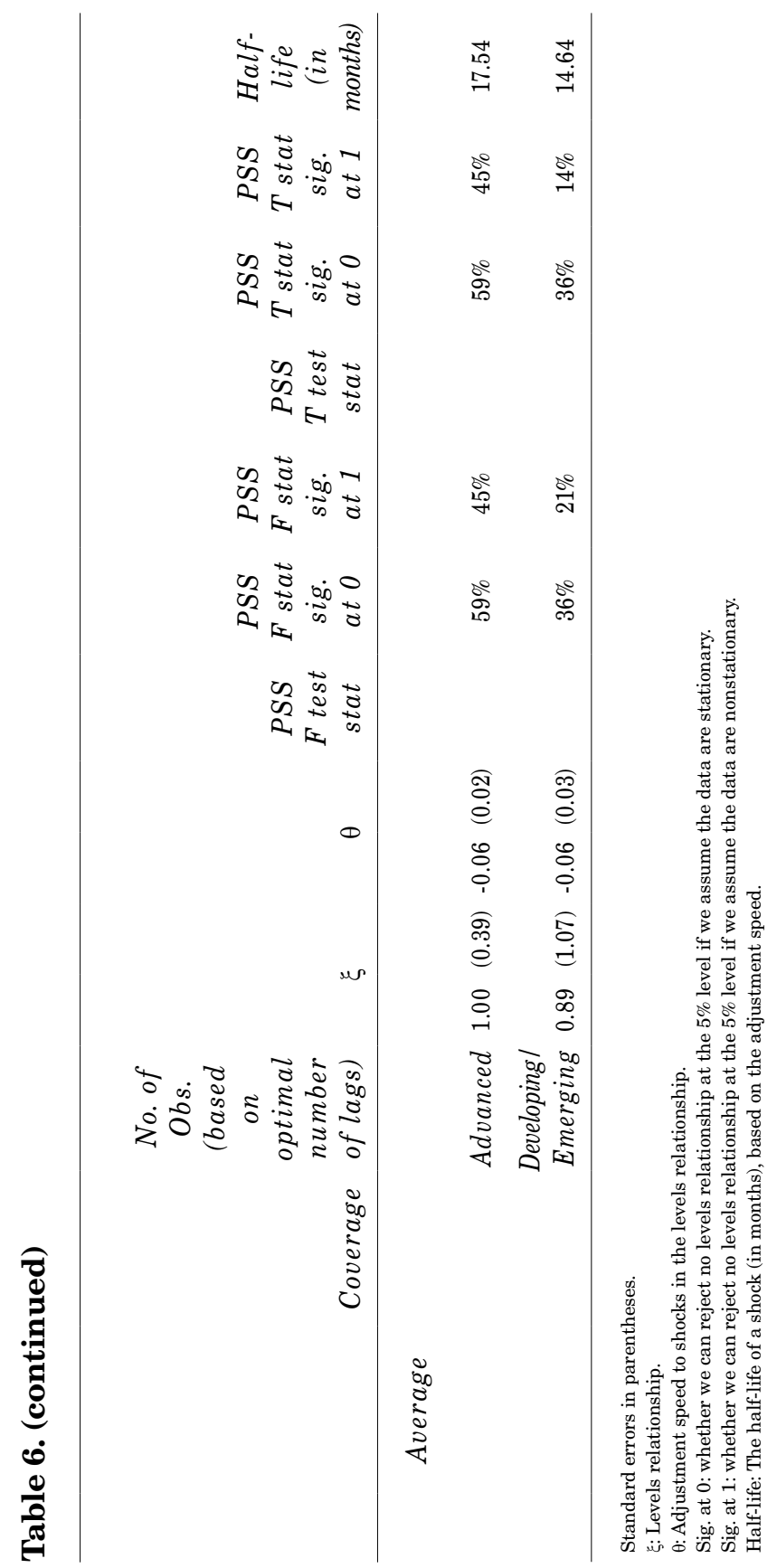




\section{Trilemmas and Tradeoffs}

In line with previous research, the results of the preceding section indicate considerable scope for countries that do not peg their exchange rates to vary short-term nominal interest rates independently of foreign nominal interest rates. In addition, changes in short-term rates appear to reflect changes in domestic variables such as inflation and output. Independence of long-term rates seems lower, regardless of the exchange regime, and the relation of changes in long-term rates to key domestic macro variables is more tenuous.

Rey (2013) summarizes earlier studies and new evidence of her own suggesting that foreign financial shocks beside interest rates spill across national borders, even when exchange rates are flexible. She concludes that:

Monetary conditions are transmitted from the main financial centers to the rest of the world through gross credit flows and leverage, irrespective of the exchange rate regime.... Fluctuating exchange rates cannot insulate economies from the global financial cycle, when capital is mobile. The "trilemma" morphs into a "dilemma"-independent monetary policies are possible if and only if the capital account is managed, directly or indirectly, regardless of the exchange-rate regime.

Because nominal interest-rate independence is demonstrably less where currencies are pegged, one is led to ask if this interestrate independence matters at all. Is there any advantage to having a flexible exchange rate? Rose (2014), for example, shows that it is hard to detect systematic differences between economic outcomes for hard currency pegs and inflation targeting regimes for small economies. As he acknowledges, however, currency regime choice is not exogenous (and, in particular, seems related to the degree of democracy). Di Giovanni and Shambaugh (2008) take a more direct approach to seek benefits from partial independence of interest rates. They demonstrate that comparative interest-rate independence allows countries with flexible exchange rates to shield themselves from the contractionary output effects of higher interest rates abroad. In contrast, countries with pegs suffer more. ${ }^{30}$

Such evidence suggests that, provided an EME's policy interest rate feeds through to other domestic interest rates and demand,

30. Aizenman, Chinn and Ito (2010) report a similar finding and also trace different country groups' approaches to navigating the monetary trilemma over time. 
its central bank retains a capacity to steer the economy, and the capacity is greater the more willing the bank to allow exchange rates to fluctuate and depart from the U.S. interest rate. Klein and Shambaugh (2013) present striking confirmation that even countries that dampen exchange rate fluctuations still enjoy some short-term interest-rate independence (though not as much as those that freely float). And of course, countries that manage exchange rates flexibly (or let them float) do not provide a one-way bet for speculators-they seem to be less susceptible to various types of crisis, including growth collapses of the type seen recently in some eurozone countries. ${ }^{31}$

Thus, it strikes me as not really fruitful to ask if the exchangerate regime materially influences the scope for monetary policy independence. Of course it does. It is unquestionably true, as Rey asserts, "monetary conditions are transmitted from the main financial centers to the rest of the world through gross credit flows and leverage." However, the exchange rate regime is central to the channels of transmission and to the range of policy responses available. The monetary trilemma remains valid.

This is not to say that even monetary independence makes the available menu of options attractive when the capital account is fully open. We learned soon after the fall of the Bretton Woods system in 1973 that floating exchange rates could be helpful in the face of some economic shocks but almost never provide full insulation against disturbances from abroad. Rather, they provide an expanded choice menu for policymakers, but with no guarantee that the available choices will be pleasant. This has proven especially true in the face of recent financial cycles in the rich economies. The monetary trilemma remains, but the difficulty of the tradeoffs that alternative policy choices entail can be worsened by financial globalization.

To understand the tradeoff problem we need to ask what exactly monetary policy autonomy or independence means. I would define it as the ability to pursue a range of domestic goals. An exchange rate peg clearly precludes this pursuit when capital flows freely across the border. Woodford's (2010) analysis demonstrates that when there is one target only-an inflation rate-then monetary autonomy is possible if the exchange rate floats. Woodford shows within a variety of New Keynesian models that under a float, the central bank can

31. See Ghosh, Ostry and Qureshi (2015). Rose's (2014) discussion points to the recent durability of flexible exchange-rate/inflation targeting regimes. 
always shift the dynamic aggregate demand curve to achieve a desired inflation target.

Normally, however, the monetary authority has multiple goals, and this is where the tradeoff problem arises.

Even in a hypothetical closed economy, monetary policy faces difficult tradeoffs. The most basic is that between inflation and unemployment. Under certain favorable conditions-essentially, that price pressure (as modeled by a New Keynesian Phillips curve) depends only upon the gap between output and its firstbest level-there is no tradeoff, as monetary policy can hit both targets simultaneously. This is Blanchard and Galís (2007) "divine coincidence." But in general, for example, when there are real wage rigidities, the coincidence fails, and the single instrument of monetary policy has somehow to navigate between the two targets, minimizing a policy loss function subject to a less favorable inflation/ unemployment tradeoff.

Opening up the economy may raise further non-financial problems because the impact of exchange-rate changes on sectoral resource allocation and income distribution is generally far from neutral. Neither in theory not in practice is there generally a "divine coincidence" for the exchange rate.

Speaking from the central banker's perspective, Fischer (2010) summarizes eloquently:

Not infrequently we hear central bankers say something like: "We have only one instrument, money growth (or the interest rate), and so we can have only one target, inflation." This view may be based on the targets and instruments approach of Tinbergen, of over fifty years ago, the general result of which was that you need as many instruments as targets. That view is correct if you have to hit the target exactly.

But it is not correct if the problem is set up as is typical in microeconomics, where the goal is to maximize a utility function subject to constrains, in a situation where for whatever reason it is not possible to hit all the targets precisely and all the time. Among the reasons we may not be abble to hit our targets precisely and all the time is that there may be more targets than instruments, for instance when the central bank's maximum is a function of output and growth. In that case we have to find marginal conditions for a maximum, and talk about tradeoffs in explaining the optimum.

Most relevant for the present discussion are the implications for financial stability. The GFC and euro crises underscore that the 
tradeoff problem arises, even in a closed economy, when monetary policy is additionally burdened with a financial stability remit. In an economy with nominal rigidities, for example, excessive private borrowing may entail negative demand externalities, which private agents do not internalize (see Eggertsson and Krugman, 2012; Farhi and Werning, 2013; among others). High debt may then lead to recession and liquidity traps. If authorities do not have the firstbest tools available to correct the externalities from debt issuance, then even in an economy characterized by a "divine coincidence" between output and inflation goals, monetary policy might need to deviate from price stability and full employment in order to restrain debt buildups. In the absence of effective macroprudential tools, an optimal monetary policy could be drawn away from exclusive devotion to traditional macroeconomic goals (even if these would be attainable absent financial stability concerns).

In this hypothetical closed-economy setting, monetary policy does not become ineffective, but "independence" of monetary policy certainly remains; however, because authorities now face a tradeoff between standard macro objectives and other targets, they will intentionally set monetary policy so as to miss all targets in a way that balances the marginal costs of the various discrepancies. Monetary policy simply carries a bigger burden than it would without financial-market distortions.

No one would expect this problem to disappear in an open economy, especially when its capital account is full open. And it does not. By themselves, exchange-rate changes would not shut out global financial developments even for policymakers willing to allow exchange rates to float free of intervention. Several theoretical models provide ample confirmation that even in the unrealistically favorable case where national policymakers cooperate, financial frictions that cannot be addressed through other tools will lead to deviations from price stability. ${ }^{32}$

Indeed, the problem confronting monetary policy is likely to be even worse in the open economy, because openness to global financial markets will inevitably degrade the effectiveness of the macroprudential tools that are available. The tradeoff between macro stabilization and financial stability becomes even worse in the sense that the optimal monetary policy will deviate even more from firstbest macro stabilization than in the closed economy. If the effects

32. For a recent contribution, see Kolasa and Lombardo (2014). 
of monetary tools are weakened because of openness, tradeoffs will become harsher still. Despite this, independent monetary policy will still be possible, and more so the less tightly the exchange rate is managed. For example, if a bigger interest rate change is needed to bring about a given demand response in an open economy, this may worsen the macro-prudential problem by increasing the fragility of banks and encouraging gross financial inflows.

The proposition that the efficacy of financial stability policies is weakened in the open economy follows from the financial trilemma formulated by Schoenmaker (2013). According to this trilemma, only two of the following three can be enjoyed simultaneously:

1. National control over financial policies.

2. Financial integration with the global market.

3. Financial stability.

For example, it may do little good to place restrictions on lenders within one's jurisdiction if foreign lenders can enter the market and operate without restriction. As another example, direct limitation of residents' domestic foreign-currency borrowing is less effective if the same entities can issue foreign-currency debt in offshore markets. ${ }^{33}$

Moreover, the reliance of financial insurance and resolution policies on the national budget can segment global financial and capital markets along national lines (while also damaging stability), as in the eurozone today. In a world of large-scale globalized finance, countries need to preserve precautionary fiscal space against financial crises. Thus, the financial trilemma can imply heavier constraints on fiscal policy as well as on monetary policy in its pursuit of domestic objectives.

Of course, the Basel Committee on Banking Supervision has been grappling with the financial trilemma since 1974, gradually but continually extending the scope and efficacy of international regulatory cooperation. The Basel III blueprint is part of the latest reform wave. Significantly (as observed by Borio, McCauley and McGuire, 2011), Basel III calls for jurisdictional reciprocity in the application of countercyclical capital buffers so that foreign banks with loans to a country that has invoked the supplementary capital

33. Ostry, Ghosh, Chamon, and Qureshi (2012) assess the effects of macroprudential and capital-control policies for a sample of 51 EMEs over 1995-2008. While finding that these policies can favorably influence aggregate indicators of financial fragility, they note the difficulty of using macroprudential policy effectively when activity can migrate to unregulated venues. 
buffer are also subject to the buffer with respect to those loans. ${ }^{34} \mathrm{By}$ raising the effectiveness of domestic authorities' macro-prudential tools, this provision reduces the burden on monetary policy. ${ }^{35}$

To summarize, even for small economies buffeted by a global financial cycle, the monetary trilemma is still valid: with open capital markets, monetary authorities have far more room for maneuver than if they pegged the exchange rate. That does not mean their lives will be easy, however. Because of the financial trilemma, the impact of monetary policy on financial stability will inevitably play a bigger role in their decisions. In the face of a less favorable tradeoff between financial and macro stability, they may well be forced farther from both.

\section{Conclusion}

Smaller economies face downsides in living with globalization. There is an inherent tension between lowering trade barriers-an approach that offers a range of gains from trade-and the implied necessity for exposing oneself to shocks and trends from abroad. These foreign disturbances range from external relative price trends that alter the home income distribution, to financial developments of the type discussed above. Government policies, including monetary and financial policies, have the potential to move the economy to a preferred point on the tradeoff between downsides and benefits.

Inefficacy of one policy instrument, however, raises the burden on the others, leaving the economy worse off in general. I have argued that while globalization places some limits on monetary policy, even with flexible exchange rates, the bigger problem is the enhanced difficulty of effective financial policy in an open economy: the financial trilemma. As for monetary policy, most emerging economies that have chosen a resolution of the monetary trilemma based on exchange rate flexibility have gained.

The paper's analysis raises questions for both future research and policy:

34. See Basel Committee on Banking Supervision (2011, p. 58, n. 49).

35. Some countries are also taking unilateral action. For example, the Federal Reserve, in February 2014, required foreign banking organizations with sufficiently large U.S. assets to set up U.S. intermediate holding companies for their American subsidiaries. These holding companies will be subject to U.S. regulation. 
- One of the most potent channels for international monetary and financial transmission clearly runs through long-term interest rates. What factors are most important in determining these correlations-expected short-term rates, term premiums, or currency risk premiums? And what are the implications for domestic monetary control?

- If capital flows create a severe tradeoff problem and macroprudential policies are weakened by imperfect international coordination, then as Rey (2013) points out, the costs and benefits of capital controls come into focus. When are capital controls helpful, what types of controls are even effective, and what globally agreed norms and procedures might allow controls to play a constructive role in the international system? In particular, in what ways does it matter that countries might use capital controls to pursue competitiveness as well as financial stability goals?

- If explicit regular coordination of central bank monetary policies is unrealistic, are there other areas for cooperation that could partially substitute and thereby supplement the Basel process? One potential example is the network of central bank swap lines introduced during the GFC, and established on a permanent basis among six advanced-country central banks in October 2013. This innovation effectively allows the lender-of-last resort function to be practiced in multiple currencies. Could it gradually be extended to a broader set of participant countries?

In discussing measures to mitigate the downsides of financial globalization, it is important to keep the upsides in view. Financial market integration promotes not just gross debt expansion through two-way capital flows, but also international risk sharing. The trend shift from foreign debt to equity finance, illustrated in figures 3 and 4 , is a stabilizing effect of globalization with the potential to make domestic monetary policy more, not less, effective. Thus, policies to discourage debt finance further, including the very high debt levels of globally active banks, have considerable potential to raise national welfare. 


\section{DATA APPENDIX}

Short-term interest rates: Three-month, local-currency, shortterm interest rates come from the Global Financial Data database. Three-month treasury bill rates are used for all countries, other than Libor-like three-month money market rates for Azerbaijan, Moldova, Oman, Qatar, and Vietnam. In a few cases (e.g., Kenya), treasury bill rate data are the time series reported by central banks and government statistical agencies. The quarterly data analyzed are averages of end-month rates.

Long-term interest rates: Ten-year, local-currency, government bond rates come from Thomson Reuters Datastream and the Global Financial Data database. The quarterly data analyzed are averages of end-month rates.

Consumer price indices: Monthly consumer price indices (CPI) from Thomson Reuters Datastream and Global Financial Data. For Australia, producer price index.

Real GDP: Quarterly seasonally adjusted GDP data from Thomson Reuters Datastream, OECD, Eurostat, and the Federal Reserve Economic Data (FRED) database of the St. Louis Fed. Where necessary, nominal GDP data were deflated by the GDP deflator and non-seasonally adjusted data were adjusted. Seasonal adjustments were based on the X-12-ARIMA quarterly seasonal adjustment method from the U.S. Census Bureau. The following countries' GDP data were seasonally adjusted by this method: Armenia, Brazil, China, Croatia, Egypt, Hong Kong, Hungary, India, Indonesia, Jordan, Kazakhstan, Latvia, Nigeria, and Poland.

Pegs/non-pegs: The paper uses Klein and Shambaugh's (2013) annual de facto coding method to distinguish pegs from non-pegs, but I apply it at quarterly frequency and require that a peg lasts at least eight consecutive quarters. In the present paper, only the most restricted classification of pegs is used (that is, soft pegs, as defined by Klein and Shambaugh, are not considered to be pegs). Pegs are defined as restricted within a $+/-2 \%$ band relative to the base country currency. The Klein-Shambaugh soft pegs move within a +/- $5 \%$ band.

Base countries: From Klein and Shambaugh (2013). The only exceptions are Cyprus and Malta, assigned the base country of Germany rather than France. Taiwan, not included in the KleinShambaugh sample, has the U.S. as its base country.

CBOE S\&P 500 Volatility Index (VIX): Quarterly average of end-month data, from Global Financial Data. 
Data coverage for the dynamic interest-rate equations is detailed by country in tables 5 and 6 . Coverage for the pooled/panel regressions (tables 1-4) is as follows:

\begin{tabular}{|c|c|c|c|c|}
\hline & Advanced & $\begin{array}{c}\text { Base } \\
\text { currency }\end{array}$ & $\begin{array}{c}L R \text { pooled / } \\
\text { panel }\end{array}$ & $\begin{array}{l}S R \text { pooled / } \\
\text { panel }\end{array}$ \\
\hline 1 & Australia & U.S. & Q3 $1989-$ Q4 2013 & Q3 $1989-$ Q4 2013 \\
\hline 2 & Austria & Germany & Q3 1989 - Q4 2013 & Q3 1989-Q4 1990 \\
\hline 3 & Belgium & Germany & Q2 1995 - Q4 2013 & Q2 1995-Q4 2013 \\
\hline 4 & Canada & U.S. & Q3 $1989-$ Q4 2013 & Q3 1989 - Q4 2013 \\
\hline 5 & Cyprus & Germany & Q1 1998 - Q4 2013 & Q2 $1995-$ Q1 2008 \\
\hline 6 & Denmark & Germany & Q2 1991 - Q4 2013 & Q2 1991 - Q4 2013 \\
\hline 7 & Finland & Germany & Q2 1990 - Q4 2013 & Q2 2012 - Q2 2013 \\
\hline 8 & France & Germany & Q3 $1989-$ Q4 2013 & Q3 $1989-$ Q4 2013 \\
\hline 9 & Germany & U.S. & Q2 1991 - Q4 2013 & Q2 1991 - Q4 2013 \\
\hline 10 & Greece & Germany & Q2 2000-Q2 2008 & Q2 2000-Q2 2008 \\
\hline 11 & Iceland & U.S./Germany & Q2 $2004-$ Q4 2013 & Q2 $1997-$ Q1 2013 \\
\hline 12 & Ireland & Germany & Q2 1997 - Q4 2013 & Q2 $1997-$ Q4 2013 \\
\hline 13 & Italy & Germany & Q2 1991 - Q4 2013 & Q2 $1991-$ Q4 2013 \\
\hline 14 & Japan & U.S. & Q3 1989 - Q4 2013 & Q3 1989 - Q4 2013 \\
\hline 15 & Malta & Germany & Q2 2000-Q4 2007 & Q2 $2000-$ Q4 2007 \\
\hline 16 & Netherlands & Germany & Q3 $1989-$ Q4 2013 & Q3 $1989-$ Q4 2013 \\
\hline 17 & Norway & Germany & Q3 1989 - Q4 2013 & Q3 $1989-$ Q4 2013 \\
\hline 18 & Portugal & Germany & Q2 1995 - Q4 2013 & Q2 1995-Q4 2013 \\
\hline 19 & Spain & Germany & Q2 1995 - Q4 2013 & Q2 $1995-$ Q4 2013 \\
\hline 20 & Sweden & Germany & Q2 1993 - Q4 2013 & Q2 $1993-$ Q4 2013 \\
\hline 21 & Switzerland & Germany & Q3 1989 - Q4 2013 & Q3 $1989-$ Q4 2013 \\
\hline 22 & United Kingdom & Germany & Q3 1989 - Q4 2013 & Q3 $1989-$ Q4 2013 \\
\hline
\end{tabular}




\begin{tabular}{|c|c|c|c|c|}
\hline & $\begin{array}{c}\text { Non- } \\
\text { Advanced }\end{array}$ & $\begin{array}{c}\text { Base } \\
\text { currency }\end{array}$ & $\begin{array}{c}L R \text { pooled / } \\
\text { panel }\end{array}$ & $\begin{array}{l}S R \text { pooled / } \\
\text { panel }\end{array}$ \\
\hline 1 & Albania & Germany & .. & Q2 2005- Q4 2013 \\
\hline 2 & Argentina & U.S. & .. & Q4 $2002-\mathrm{Q} 42013$ \\
\hline 3 & Armenia & U.S. & .. & Q2 1996- Q4 2013 \\
\hline 4 & Brazil & U.S. & Q1 $2000-\mathrm{Q} 42006$ & Q2 $1995-$ Q4 2012 \\
\hline 5 & Bulgaria & Germany & Q3 $1993-$ Q3 2009 & Q2 $1997-$ Q1 2008 \\
\hline 6 & Chile & U.S. & Q4 $2004-$ Q4 2013 & Q2 2003- Q3 2012 \\
\hline 7 & China & U.S. & Q1 2007 - Q4 2013 & Q3 1997 - Q4 2013 \\
\hline 8 & Colombia & U.S. & Q4 $2002-$ Q4 2013 & Q2 $2000-$ Q3 2012 \\
\hline 9 & Croatia & Germany & Q2 2012- Q3 2013 & Q2 2006 - Q3 2013 \\
\hline 10 & Czech Republic & Germany & Q3 $2000-$ Q4 2013 & Q1 1996- Q4 2013 \\
\hline 11 & Egypt & U.S. & .. & Q2 2007- Q4 2013 \\
\hline 12 & Ghana & U.S. & .. & Q2 $2006-$ Q2 2013 \\
\hline 13 & Hong Kong & U.S. & Q1 1997- Q4 2013 & Q3 1991 - Q4 2013 \\
\hline 14 & Hungary & U.S./Germany & Q2 $1999-$ Q4 2013 & Q2 1995- Q4 2013 \\
\hline 15 & India & U.S. & Q3 $2004-$ Q4 2013 & Q3 $2004-$ Q4 2013 \\
\hline 16 & Indonesia & U.S. & Q3 2009- Q4 2013 & Q2 $2000-$ Q4 2003 \\
\hline 17 & Israel & U.S. & Q2 2006 - Q4 2013 & Q2 2006 - Q4 2013 \\
\hline 18 & Kazakhstan & U.S. & Q2 $1998-$ Q4 2013 & Q3 $1994-$ Q4 2013 \\
\hline 19 & Kenya & U.S. & Q2 2011- Q3 2013 & Q2 2000- Q3 2013 \\
\hline 20 & Latvia & U.S./Germany & Q1 $1999-$ Q4 2013 & Q2 $1995-$ Q4 2013 \\
\hline 21 & Mexico & U.S. & Q1 $2000-$ Q4 2013 & Q2 $1993-$ Q4 2013 \\
\hline 22 & Nigeria & U.S. & Q2 2009 - Q3 2013 & Q3 1995 - Q3 2013 \\
\hline 23 & Philippines & U.S. & Q2 1999 - Q3 2013 & Q2 1998 - Q4 2013 \\
\hline 24 & Poland & Germany & Q3 1999- Q4 2013 & Q2 1996 - Q4 2013 \\
\hline 25 & Romania & U.S./Germany & Q2 2012- Q4 2013 & Q2 2000- Q3 2005 \\
\hline
\end{tabular}


(continued)

\begin{tabular}{|c|c|c|c|c|}
\hline & $\begin{array}{c}\text { Non- } \\
\text { Advanced }\end{array}$ & $\begin{array}{c}\text { Base } \\
\text { currency }\end{array}$ & $\begin{array}{l}L R \text { pooled I } \\
\text { panel }\end{array}$ & $\begin{array}{l}S R \text { pooled I } \\
\text { panel }\end{array}$ \\
\hline 26 & Russia & U.S. & Q2 2003 - Q3 2013 & Q2 $2003-$ Q3 2013 \\
\hline 27 & Singapore & Malaysia & Q3 1998 - Q4 2013 & Q3 1989 - Q4 2013 \\
\hline 28 & Slovakia & Germany & Q2 1997-Q4 2013 & Q2 $1997-$ Q4 2007 \\
\hline 29 & Slovenia & Germany & Q2 2002 - Q4 2013 & Q3 $2000-$ Q4 2013 \\
\hline 30 & South Africa & U.S. & Q3 1989 - Q4 2013 & Q3 $1989-$ Q4 2013 \\
\hline 31 & South Korea & U.S. & Q1 2001 - Q4 2013 & Q4 2006-Q42013 \\
\hline 32 & Taiwan & U.S. & Q2 1995- Q4 2013 & Q3 $1989-$ Q4 2013 \\
\hline 33 & Thailand & U.S. & Q2 1993 - Q4 2013 & Q2 1997 - Q4 2013 \\
\hline 34 & Turkey & U.S. & Q2 2012 - Q4 2013 & Q2 $1998-$ Q4 2013 \\
\hline
\end{tabular}




\section{REFERENCES}

Aizenman, J., M.D. Chinn and H. Ito. 2010. "The Emerging Global Financial Architecture: Tracing and Evaluating New Patterns of the Trilemma Configuration." Journal of International Money and Finance 29 (June 2010): 615-41.

Bacha, E.L. and C.F. Diaz-Alejandro. 1982. "International Financial Intermediation: A Long and Tropical View," Essays in International Finance 147. Princeton, NJ: International Finance Section, Department of Economics, Princeton University, 1982.

Basel Committee on Banking Supervision. 2011. "Basel III: A Global

Framework for More Resilient Banks and Banking Systems." Bank for International Settlements, revised June 2011.

Bernanke, B.S. 2013. "Long-Term Interest Rates." Speech at the Federal Reserve Bank of San Francisco, March 1, 2013. Available at: http: / / www.federalreserve.gov / newsevents / speech / bernanke20130301a.pdf

Blanchard, O.J. and J. Galí. 2007. "Real Wage Rigidities and the New Keynesian Model." Journal of Money, Credit, and Banking 39 (1, 2007): Supplement, 35-65.

Bluedorn, J.C. and C. Bowdler. 2010. "The Empirics of International Monetary Transmission: Identification and the Impossible Trinity." Journal of Money, Credit, and Banking 42 (June 2010): 679-713.

Borio, C. 2012. "The Financial Cycle and Macroeconomics: What Have We Learnt?" BIS Working Papers 395, December 2012.

Borio, C. and P. Disyatat. 2011. "Global Imbalances and the Financial Crisis: Link or No Link?” BIS Working Papers 346 (May 2011).

Borio, C., R. McCauley and P. McGuire. 2011. "Global Credit and Domestic Credit Booms." BIS Quarterly Review (September 2011): 43-57.

Broner, F., T. Didier, A. Erce, and S.L. Schmukler. 2013. "Gross Capital Flows: Dynamics and Crises." Journal of Monetary Economics 60 (2013): 113-33.

Bruno, V. and H.S. Shin. 2013. "Capital Flows and the Risk-Taking Channel of Monetary Policy." NBER Working Paper 18942, April 2013.

Bussière, M., G. Cheng, M. Chinn, and N. Lisack. 2014. "For a Few Dollars More: Reserves and Growth in Times of Crises." NBER Working Paper 19791, January 2014. 
Calvo, G.A., L. Leiderman and C.M. Reinhart. 1993. "Capital Inflows and Real Exchange Rate Appreciation in Latin America: The Role of External Factors." IMF Staff Papers 40 (March 1993): 108-151. Calvo, G.A., L. Leiderman and C.M. Reinhart. 1996. "Inflows of Capital to Developing Countries in the 1990s." Journal of Economic Perspectives 10 (Spring 1996): 123-39.

Calvo, G.A. and E.G. Mendoza. 2000. "Rational Contagion and the Globalization of Securities Markets." Journal of International Economics 51 (June 2000).

Calvo, G.A. and C.M. Reinhart. 2002. "Fear of Floating." Quarterly Journal of Economics 117 (May 2002): 379-408.

Caruana, J. 2012. "International Monetary Policy Interactions: Challenges and Prospects." Speech at the CEMLA-SEACEN Conference, Punta del Este, Uruguay, November 16, 2012. Available at: http://www.bis.org/speeches/sp121116.pdf

Cetorelli, N. and L.S. Goldberg. 2011. "Global Banks and International Shock Transmission: Evidence from the Crisis." IMF Economic Review 59 (1, 2011): 41-76.

Chinn, M.D. and H. Ito. 2006. "What Matters for Financial Development? Capital Controls, Institutions, and Interactions." Journal of Development Economics 81 (October 2006): 163-92.

Chinn, M.D. and S. Quayyum. 2012. "Long Horizon Uncovered Interest Parity Re Assessed." Mimeo, University of Wisconsin, October 2012.

Ciccarelli, M. and B. Mojon. 2010. "Global Inflation." Review of Economics and Statistics 92 (August 2010): 524-35.

Committee on the Global Financial System. 2011. "Global Liquidity -Concept, Measurement and Policy Implications." CGFS Papers 45, Bank for International Settlements, November 2011.

Cowan, K., J. De Gregorio, A. Micco, and C. Neilson. 2008. "Financial Diversification, Sudden Stops, and Sudden Starts." In Current Account and External Financing, edited by K. Cowan, S. Edwards, and R. Valdés, Santiago, Chile: Central Bank of Chile, 2008.

Dahlquist, M. and H. Hasseltoft. 2012. "International Bond Risk Premia." Mimeo, Stockholm School of Economics and University of Zurich, August 2012.

Dell'Ariccia, G., L. Laeven and G. Suarez. 2013. "Bank Leverage and Monetary Policy's Risk-Taking Channel: Evidence from the United States." IMF Working Paper WP/13/143, June 2013. 
Di Giovanni, J. and J.C. Shambaugh. 2008. "The Impact of Foreign Interest Rates on the Economy: The Role of the Exchange Rate Regime." Journal of International Economics 74 (2008): 341-61.

Dominguez, K.M.E., Y. Hashimoto and T. Ito. 2012. "International Reserves and the Global Financial Crisis." Journal of International Economics 88 (November 2012): 388-406.

Eggertsson, G.B. and P. Krugman. 2012. "Debt, Deleveraging, and the Liquidity Trap: A Fisher-Minsky-Koo Approach." Quarterly Journal of Economics 127 (August 2012): 1469-513.

Eichengreen, B. 1991. "Trends and Cycles in Foreign Lending." In Capital Flows in the World Economy: Symposium 1990, edited by H. Siebert. Tübingen, Germany: J.C.B. Mohr, 1991.

Farhi, E. and I. Werning. 2013. "A Theory of Macroprudential Policies in the Presence of Nominal Rigidities." NBER Working Paper 19313, August 2013.

Filardo, A., H. Genberg and B. Hofmann. 2014. "Monetary Analysis and the Global Financial Cycle: An Asian Central Bank Perspective." Mimeo, May 2014.

Fischer, S. 2010. "Myths of Monetary Policy." Israel Economic Review 8 (2, 2010): 1-5.

Forbes, K.J. and F.E. Warnock. 2012. "Capital Flow Waves: Surges, Stops, Flight, and Retrenchment." Journal of International Economics 88 (2012): 235-51.

Frankel, J., S.L. Schmukler, and L. Servén. 2004. "Global Transmission of Interest Rates: Monetary Independence and Currency Regime." Journal of International Money and Finance 23 (2004): 701-33.

Gertler, M. and P. Karadi. 2011. "A Model of Unconventional Monetary Policy.” Journal of Monetary Economics 58 (January 2011): 17-34. Ghosh, A.R., J.D. Ostry, and M.S. Qureshi. 2015. "Exchange Rate Management and Crisis Susceptibility: A Reassessment." IMF Economic Review, 63(1): 238-76.

Goldberg, L.S. 2013. "Banking Globalization, Transmission, and Monetary Policy Autonomy." Penning- och valutapolitik $(3,2013)$ : 161-93.

Gonzáles-Rozada, M. and E.L. Yeyati. 2008. "Global Factors and Emerging Market Spreads." Economic Journal 118 (November 2008): 1917-936.

Gourinchas, P.O. 2012. "Global Imbalances and Global Liquidity." In Asia's Role in the Post-Crisis Global Economy, edited by R. Glick and M.M. Spiegel, 2011 Asia Economic Policy Conference. San Francisco: Federal Reserve Bank of San Francisco, 2012. 
Gourinchas, P.O. and O. Jeanne. 2013. Capital Flows to Developing Countries: The Allocation Puzzle." Review of Economic Studies 80 (October 2013): 1484-515.

Gourinchas, P.O. and M. Obstfeld. 2012. "Stories of the Twentieth Century for the Twenty-First." American Economic Journal: Macroeconomics 4 (January 2012): 226-65.

Hausmann, R., U. Panizza and E. Stein. 2001. "Why Do Countries Float the Way They Float?" Journal of Development Economics 66 (2001): 387-414.

He, D. and R.N. McCauley. 2013. "Transmitting Global Liquidity to East Asia: Policy Rates, Bond Yields, Currencies and Dollar Credit." BIS Working Papers 431, October 2013.

Hellerstein, R. 2011. "Global Bond Risk Premiums.” Staff Report 499, Federal Reserve Bank of New York, June 2011.

Ivashina, V., D.S. Scharfstein and J.C. Stein. 2012. "Dollar Funding and the Lending Behavior of Global Banks." Mimeo, Harvard University, October 2012.

Klein, M.W. and J.C. Shambaugh. 2013. "Rounding the Corners of the Policy Trilemma: Sources of Monetary Policy Autonomy.” NBER Working Paper 19461, September 2013.

Kolasa, M. and G. Lombardo. 2014. "Financial Frictions and Optimal Monetary Policy in an Open Economy." International Journal of Central Banking 10 (March 2014): 43-94.

Landau, J.P. 2014. "Global Liquidity: Public and Private." In Global Dimensions of Unconventional Monetary Policy, 2013 Jackson Hole Symposium Proceedings. Kansas City, MO: Federal Reserve Bank of Kansas City, 2014.

Lane, P.R. and P. McQuade. 2014. "Domestic Credit Growth and International Capital Flows." Scandinavian Journal of Economics 116 (January 2014): 218-52.

Lane, P.R. and G.M. Milesi-Ferretti. 2007. "The External Wealth of Nations, Mark II: Revised and Extended Estimates of Foreign Assets and Liabilities, 1970-2004." Journal of International Economics 73 (November 2007): 223-50.

Lane, P.R. and J.C. Shambaugh. 2010. "Financial Exchange Rates and International Currency Exposures.” American Economic Review 100 (March 2010): 518-40.

Magud, N.E., C.M. Reinhart, and E.R. Vesperoni. 2014. "Capital Inflows, Exchange Rate Flexibility, and Credit Booms." Review of Development Economics, 18(3): 415-30. 
McCauley, R.N., P. McGuire, and V. Sushko. 2014. "Global Dollar Credit: Links to U.S. Monetary Policy and Leverage." Economic Policy, 30(82): 187-229.

McKinnon, R.I. 1982. "Currency Substitution and Instability in the World Dollar Standard." American Economic Review 72 (June 1982): 320-33.

Miniane, J. and J.H. Rogers. 2007. "Capital Controls and the International Transmission of U.S. Monetary Shocks." Journal of Money, Credit, and Banking 39 (August 2007): 1003-035.

Miyajima, K., M.S. Mohanty, and T. Chan. 2012. "Emerging Market Local Currency Bonds: Diversification and Stability." BIS Working Papers 391, November 2012.

Munro, A. and P. Wooldridge. 2012. "Motivations for Swap-Covered Foreign Currency Borrowing." In Currency Internationalisation: Lessons from the Global Financial Crisis and Prospects for the Future in Asia and the Pacific. BIS Papers 61, January 2012.

Neely, C.J. 2013. "Unconventional Monetary Policy Had Large International Effects." Working Paper 2010-018E, Federal Reserve Bank of St. Louis, August 2013.

Nurkse, R. 1954. "International Investment To-Day in the Light of Nineteenth-Century Experience." Economic Journal 64 (December 1954): 744-58.

Obstfeld, M. 2014. "Never Say Never: Commentary on a Policymaker's Reflections." IMF Economic Review, 62(4): 656-93.

Obstfeld, M., J.C. Shambaugh, and A.M. Taylor. 2005. "The Trilemma in History: Tradeoffs among Exchange Rates, Monetary Policies, and Capital Mobility." Review of Economics and Statistics 87 (August 2005): 423-38.

Obstfeld, M. and A.M. Taylor. 2004. "Global Capital Markets: Integration, Crisis, and Growth." Cambridge, UK: Cambridge University Press, 2004.

Ostry, J.D., A.R. Ghosh, M. Chamon, and M.S. Qureshi. 2012. "Tools for Managing Financial-Stability Risks from Capital Flows." Journal of International Economics 88 (2012): 407-21.

Pesaran, M.H., Y. Shin, and R.J. Smith. 2001. "Bounds Testing Approaches to the Analysis of Levels Relationships." Journal of Applied Econometrics 16 (May/June 2001): 289-326.

Prasad, E.S. 2011. "Role Reversal in Global Finance." In Achieving Maximum Long-Run Growth, 2011 Jackson Hole Symposium Proceedings. Kansas City, MO: Federal Reserve Bank of Kansas City, 2012. 
Prasad, E., R. Rajan, and A. Subramanian. 2007. "The Paradox of Capital." Finance \& Development 44 (March 2007).

Rey, H. 2013. "Dilemma not Trilemma: The Global Financial Cycle and Monetary Policy Independence." In Global Dimensions of Unconventional Monetary Policy, 2013 Jackson Hole Symposium Proceedings. Kansas City, MO: Federal Reserve Bank of Kansas City, 2014.

Rose, A.K. 2014. "Surprising Similarities: Recent Monetary Regimes of Small Economies.” Mimeo, University of California, Berkeley, February 2014.

Schoenmaker, D. 2013. "Governance of International Banking: The Financial Trilemma." Oxford, UK: Oxford University Press, 2013. Shambaugh, J.C. 2004. "The Effect of Fixed Exchange Rates on Monetary Policy." Quarterly Journal of Economics 119 (February 2004): 300-51.

Sheets, N. and R.A. Sockin. 2013. "Why Are Long-term Rates So Correlated across Countries?-The Role of U.S. Monetary Policy." Perspectives, Citi Research, 5 September 2013.

Shin, H.S. 2013. "The Second Phase of Global Liquidity and Its Impact on Emerging Economies." Speech at the Federal Reserve Bank of San Francisco, November 7, 2013. Available at: http: / / www. princeton.edu/ hsshin/www/FRBSF_2013.pdf

Turner, P. 2012. "Weathering Financial Crisis: Domestic Bond Markets in EMEs." In Weathering Financial Crises: Bond Markets in Asia and the Pacific. BIS Papers 63, January 2012. Available at: http: / / www.bis.org / publ/ bppdf / bispap63.htm

Turner, P. 2014. "The Global Long-Term Interest Rate, Financial Risks and Policy Choices in EMEs." BIS Working Papers 441, February 2014.

Wallace, M.S. 1984. "World Money or Domestic Money: Which Predicts U.S. Inflation Best?" Journal of International Money and Finance 3 (August 1984): 241-44.

Woodford, M. 2010. "Globalization and Monetary Control." In International Dimensions of Monetary Policy edited by J. Galí and M. Gertler, Chicago: University of Chicago Press, 2010. 